\title{
Age, composition, and source of the Macururé Mafic Suite, Southern Borborema Province, Brazil
}

\author{
Fábio dos Santos Pereira ${ }^{1 *}$ (D, Maria de Lourdes da Silva Rosa' (1), \\ Herbet Conceição' (1), Anelise Losangela Bertotti ${ }^{2}$
}

\begin{abstract}
The Capela, Dores, Aquidabã, Camará, Campo Grande, and Pedra Branca stocks constitute the Macururé Mafic Suite of the Sergipano Orogenic System, Southern Borborema Province. These bodies have elongated and tabular forms, which are concordant with the metasedimentary host rocks foliation. Most primitive terms are hornblendites, gabbros, and diorites, with minor monzonites, granodiorites, and granites. U-Pb SHRIMP zircon ages for Capela $(631 \pm 3 \mathrm{Ma})$, Aquidabã $(636 \pm 4 \mathrm{Ma})$ and Campo Grande $(629 \pm 9 \mathrm{Ma})$ stocks indicate the coeval emplacement of the intrusions. Geochemical data show that these rocks are metaluminous to slightly peraluminous, magnesian and have high-K calc-alkaline to shoshonitic affinities. Rare earth elements (REE) patterns are fractionated and multielement diagrams display depletions at $\mathrm{Nb}, \mathrm{Ta}$, and $\mathrm{Ti}$, indicating subduction-related magmatism. Trace elements data suggest that the gabbros and diorites were generated by partial melting of an enriched subcontinental lithospheric mantle in the spinel stability field, which has probably been metasomatized by the interaction with sediments during previous subduction events. Field and petrographic evidence, associated with geochemical and geochronological data support that the magmas of the Macururé Mafic Suite were emplaced in early-to syn-collisional stage during the build-up of a continental arc in the Sergipano Orogenic System, at ca. 630 Ma.
\end{abstract}

KEYWORDS: Mafic Magmatism; Continental Arc; Ediacaran.

\section{INTRODUCTION}

Potassic igneous rocks, such as high-K calc-alkaline and shoshonitic ones, have been described in tectonic settings of continental and oceanic arcs, and within-plate (Müller et al. 1992, Turner et al. 1996, Pe-Piper et al. 2009), assuming a significant role in the reconstruction of ancient terrenes. Shoshonitic series rocks are difficult to classify because they share features common to both calc-alkaline and alkaline series, characterized by high alkalis total, strong enrichment in incompatible trace elements and depletion in $\mathrm{Nb}, \mathrm{Ta}$, and $\mathrm{Ti}$ (e.g., Morrison 1980). Most authors attribute these features to a subcontinental lithospheric mantle or asthenospheric mantle, which has been enriched in incompatible elements during earlier subduction (Aldanmaz et al. 2000, Mariano et al. 2001, Hollanda et al. 2003). Therefore, the study of potassic mantle-derived rocks may yield important insights about the nature of the mantle reservoirs.

'Programa de Pós-Graduação em Geociências e Análise de Bacias, Universidade Federal de Sergipe - São Cristóvão (SE), Brazil. E-mails: fabio.santos.pereira@hotmail.com, lrosa@ufs.br, herbet@ufs.br

${ }^{2}$ Universidade Federal de Pernambuco - Recife (PE), Brazil.

E-mail: aneber79@gmail.com

${ }^{*}$ Corresponding author.

(C) 2020 The authors. This is an open access article distributed under the terms of the Creative Commons license.
High-K calc-alkaline to shoshonite plutonic rocks related to Brasiliano Orogeny are widely distributed in the Sergipano Orogenic System (SOS), Southern Borborema Province. Available U-Pb crystallization ages range from 625 to $588 \mathrm{Ma}$ (Long et al. 2005, Silva 2014, Conceição et al. 2017, Lisboa et al. 2019, Santos et al. 2019, Soares et al. 2019, Sousa et al. 2019), comprising plutons emplaced under different tectonic regimes. Gabbroic and dioritic microgranular enclaves with shoshonitic to ultrapotassic affinities hosted in granites, granodiorites, and monzonites have also been described (Oliveira 2014, Conceição et al. 2016, Fontes et al. 2018). However, the petrogenetic and tectonic significances of these rock associations in the SOS are not well understood.

The present work focuses on a potassic association of ultrabasic-basic-intermediate-acidic rocks, denominated Macururé Mafic Suite. These bodies have been intruded along the east margin of the SOS and were previously mapped as part of a metasedimentary sequence (Silva Filho et al. 1979, Santos et al. 1998). New whole-rock geochemical and U-Pb SHRIMP data are presented and discussed here in order to infer the possible magma sources, the petrogenetic processes and the role of this magmatism in the geotectonic evolution of the Southern Borborema Province.

\section{GEOLOGICAL SETTING}

The Borborema Province, located in northeastern Brazil, is a geotectonic unit resulting from the convergence of the Amazonian, West Africa-São Luís and São Francisco-Congo 
cratons (Fig. 1A) during the assembly of Western Gondwana. It is constituted of an essentially Paleoproterozoic gneissic and migmatitic basement (2.5-2.0 Ga) and isolated Archean blocks (3.4-2.7 Ga), partially covered by Mesoproterozoic and Neoproterozoic supracrustal sequences (Brito Neves et al.2000, Van Schmus et al. 2008, Guimarães et al. 2011). In addition, the province was affected by the Cariris Velhos $(\sim 1.0 \mathrm{Ga})$ and Brasiliano/Pan-African ( 0.6 Ga) events, this last one being responsible for low- to high-grade metamorphism, emplacement of abundant granites and development of an expressive system of continental-scale shear zones.

The E-W Patos and Pernambuco shear zones divide the Borborema Province in the Northern, Central, and Southern subprovinces (Van Schmus et al. 2008). The Southern Subprovince is situated between the Pernambuco Lineament and the São Francisco Craton and comprises the PernambucoAlagoas Superterrane (PEAL), Sergipano and Riacho do Pontal belts (Fig. 1B).

The SOS shows a triangular outline with WNW-ESE orientation (Fig. 1C). The SOS resulted from closure of an ocean basin along the northern margin of the São Francisco Craton and, in pre-drift reconstructions, represents the western extension of the Oubanguides Orogen, in NW Africa (Trompette 1997).

Different models have been proposed to explain the tectonic evolution of the SOS. It was initially interpreted as a geosyncline (Humphrey \& Allard 1969, Silva Filho et al. 1979),
A

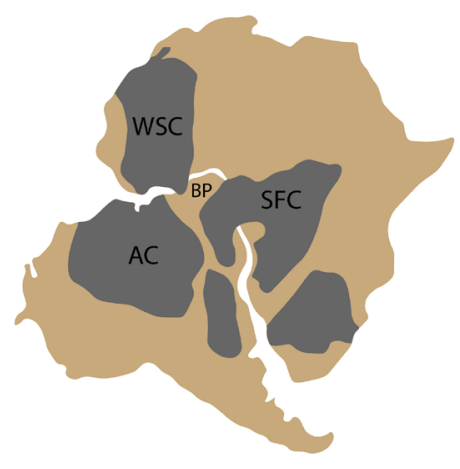

B

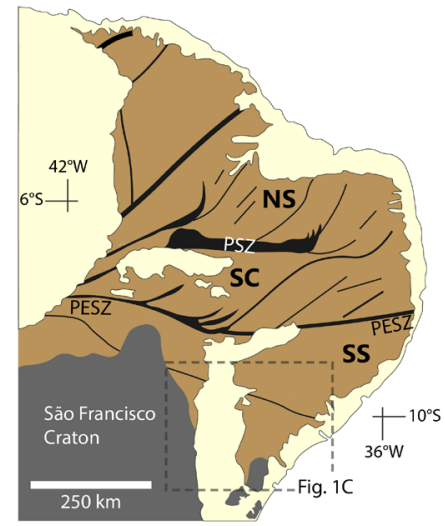

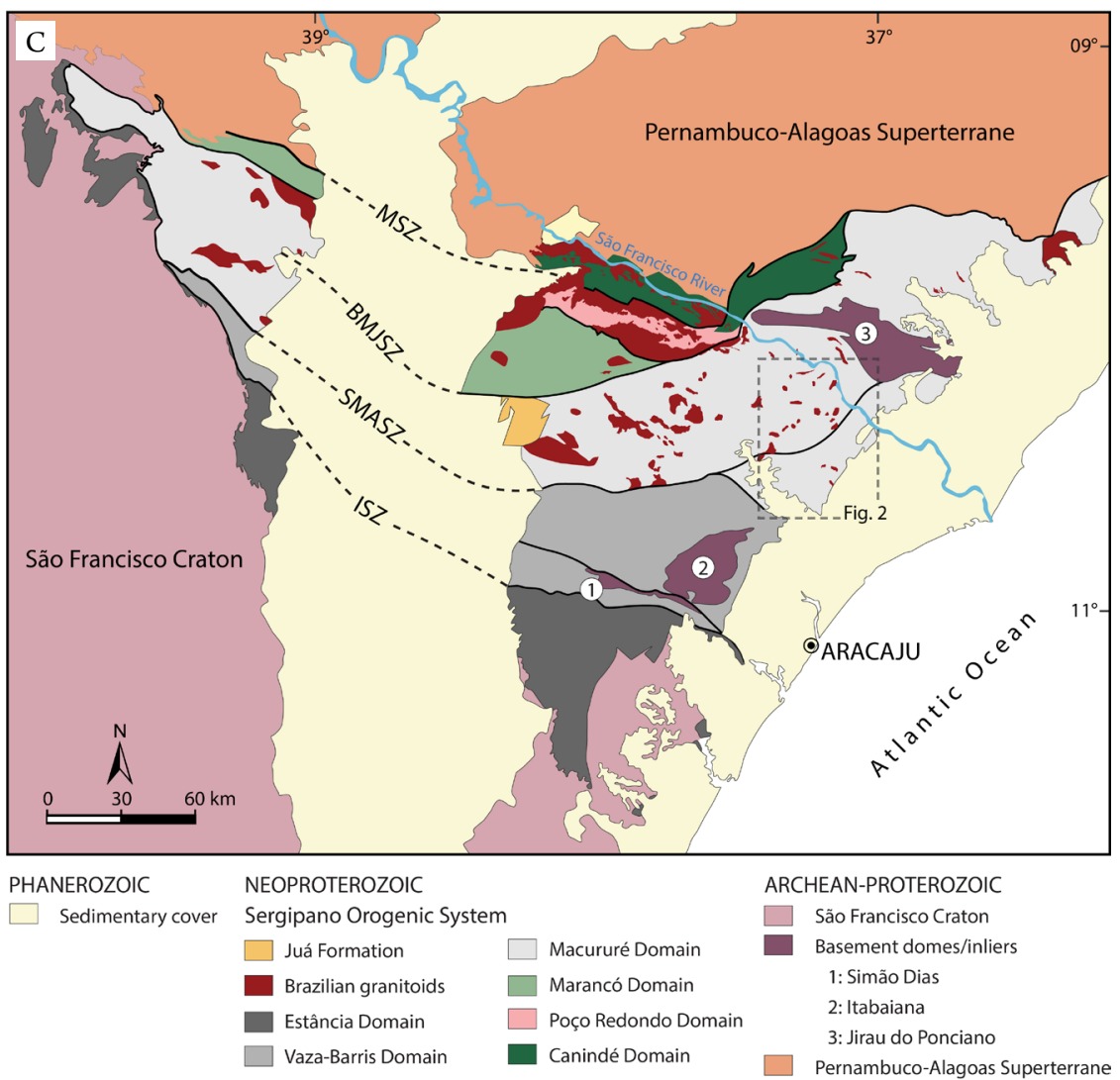

MSZ: Macururé shear zone; BMJSZ: Belo Monte-Jeremoabo shear zone; SMASZ: São Miguel do Aleixo shear zone; ISZ: Itaporanga shear zone.

Figure 1. Geological context. (A) Pre-drift reconstruction of South America-Africa showing the location of Borborema Province (BP) and Amazonian (AC), West-Africa (WSC) and São Francisco-Congo cratons (SFC). (B) Subdivision of Borborema Province in Northern (NS), Central (SC) and Southern (SS) subprovinces, limited by the shear zones systems Patos (PSZ) and Pernambuco (PESZ), according to Van Schmus et al. (2008). (C) Simplified geological map of the area outlined in (B) showing the tectonic compartmentation of the Sergipano Orogenic System according to Davison and Santos (1989). The rectangle shows the location of the study area. 
as a collage of allochthonous tectonostratigraphic terrains (Davison \& Santos 1989) and as a belts of folds and thrust belt developed by the inversion of a passive margin in the northeastern edge of the São Francisco paleoplate (D'el-Rey Silva 1999). More recent models proposed that the SOS corresponds to the result of a continental collision between the PEAL and the ancient São Francisco plate, during the Brasiliano/ Pan-African Orogeny (Oliveira et al. 2010, 2015a) or else as a product of large scale lithospheric extension and subsequent basin inversion (Neves et al. 2016).

Davison and Santos (1989) recognized six tectonic domains in the SOS: Estância, Vaza-Barris, Macururé, Marancó, Poço Redondo, and Canindé (Fig. 1C). These domains, with distinct sedimentation history and tectonic evolution, are mutually separated by regional shear zones and occur interspersed by inliers and basement domes (Simão Dias, Itabaiana and Jirau do Ponciano).

The Macururé Domain is limited to the south by the Vaza-Barris Domain and to the north by the Marancó, Poço Redondo, and Canindé domains by the São Miguel do Aleixo and Belo Monte-Jeremoabo sinistral shear zones, respectively (Fig. 1C). This domain is composed of the Macururé Group, the Juá Formation and a suite of collisional granites.

The Macururé Group is constituted of granatiferous biotite schists, phyllites, metarenites, and quartzites, with subordinate occurrences of metagreywacke, volcanic rocks, and amphibolite lenses, interspersed with centimeter-tick levels of marble, calc-silicate rocks, and banded iron formations (Santos et al. 1998, Oliveira et al. 2010). These rocks rest on the Jirau do Ponciano Dome (2063 $\pm 9 \mathrm{Ma}$; Spalletta \& Oliveira 2017), which outcrops in southeastern Alagoas and is considered as the basement of the domain.

The sedimentary sequence of the Macururé Group was interpreted as a Neoproterozoic turbiditic wedge (D’el-Rey Silva 1999, Oliveira et al.2017), based on the presence of structures indicative of deepwater deposition (Davison \& Santos 1989). Whole-rock geochemical data indicate that clastic sedimentation has been related to the erosion of intermediate to acidic sources with magmatic arc signature (Lima et al. 2014), possibly derived from the Borborema Province. Regional metamorphism reached intermediate $\mathrm{P}$ and high $\mathrm{T}$ in amphibolite facies (Davison \& Santos 1989, Silva et al. 1995), although equivalent granulites are recognized in the northernmost part of the domain (Oliveira et al. 2006). A two-point Sm-Nd isochron for a garnet micaschist provides an age of $573 \pm 1 \mathrm{Ma}$, which is interpreted as the age of the last metamorphic event affecting the Macururé Domain (Oliveira et al. 2010).

The Juá Formation is constituted of undeformed to weakly deformed polymictic conglomerates, greywacke, and coarse sandstones (Silva Filho et al. 1979, Menezes Filho et al. 1988), which fill a graben structured on the Macururé Group rocks and associated granites (Fig. 1C). These clastic sediments are interpreted as alluvial fan deposits formed from the erosion of the Marancó Domain rocks during the evolution of the SOS (Menezes Filho et al. 1988).

Plutonic igneous rocks make up to $25 \%$ of the Macururé Domain area (Davison \& Santos 1989) and have been studied by several researchers. Based on field evidence and $\mathrm{U}-\mathrm{Pb}$ dating, Bueno et al. (2009) divided the granitoids from Macururé Domain in pre- (628-625 Ma) and syn-collisional (580-570 Ma), taking as reference the main deformational event that affected this SOS sector (D2). The granitoids of the first group show evidence of solid-state deformation related to D2, while the granitoids of the second group preserve their magmatic structures paralleling to the host rocks foliation. Oliveira et al. $(2010,2015 \mathrm{~b})$ proposed that the oldest granitoids were formed in a continental arc environment, while the youngest ones have crustal derivation and were generated during the collisional event.

The Brasiliano intrusive magmatism in the eastern part of the Macururé Domain was divided by Conceição et al. (2017) into five groups:

- (G1) basic-ultrabasic, tholeiitic to calc-alkaline;

- (G2) intermediate to basic, with high-Kcalc-alkaline affinity;

- (G3) high-K calc-alkaline granodiorite;

- (G4) high-K calc-alkaline leucogranite;

- (G5) shoshonite monzonite.

The Macururé Mafic Suite (Fig. 2), which is the object of this study, occurs in the eastern segment of the SOS and corresponds to magmatic G1 and G2 groups. These bodies comprise diorites, gabbros, and hornblendites, with minor felsic terms. They are small dimension bodies $\left(1-20 \mathrm{~km}^{2}\right)$, with occur with elongated and tabular shapes concordant to the host rocks regional foliation, sometimes associated with shear zones.

The main exponents of granodiorite magmatism (G3) are the Coronel João Sá (625 $\pm 2 \mathrm{Ma}$; Long et al. 2005) and Lagoa do Roçado (618 \pm 4 Ma; Silva 2014) plutons. These rocks

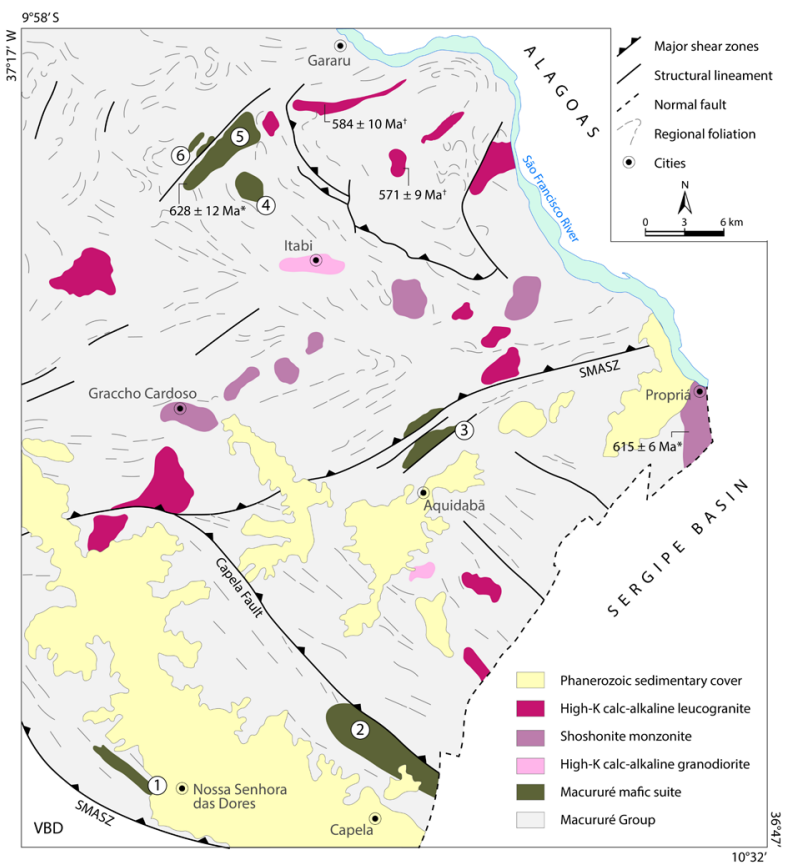

*SHRIMP in zircon; †ID-TIMS in titanite; SMASZ: São Miguel do Aleixo shear zone; VBD: Vaza Barris Domain.

Figure 2. Simplified geological map of study area indicating the location of the Dores (1), Capela (2), Aquidabã (3), Campo Grande (4), Camará (5), and Pedra Branca (6) stocks. Presented U-Pb crystallization ages from Bueno et al. (2009) and Santos et al. (2019). 
have a typical volcanic arc signature and exhibit a magmatic foliation marked by the orientation of plagioclase phenocrysts and mafic enclaves.

Biotite granites and biotite-muscovite granites (G4) occur as stocks and sheets which were emplaced along the axial plane foliation or in hinge zones of folds related to the main deformational event in Macururé Domain (Bueno et al. 2009, Conceição et al.2016, Pereira et al.2017a). These rocks are high-K calc-alkaline and record the collisional and crustal thickening episode in the SOS. Available U-Pb titanite ages for this group vary between $571 \pm 9$ and $584 \pm 10 \mathrm{Ma}$ (Bueno et al. 2009).

Monzonite magmatism (G5) is mainly represented by Glória Norte pluton, with U-Pb SHRIMP crystallization age in zircon of $588 \pm 4 \mathrm{Ma}$ (Lisboa et al. 2019). This intrusion truncate regional structures and exhibit no evidence of deformation related to $\mathrm{D} 2$, marking the post-collisional stage in the Macururé Domain. This magmatic group differs from the others by the abundance of mafic microgranular and cumulate enclaves with shoshonitic-ultrapotassic affinities (Fontes et al. 2018).

\section{FIELD RELATIONSHIPS AND PETROGRAPHY}

The studied stocks are intruded within the metasedimentary rocks of the Macururé Group along its oriental part. The host rocks are granatiferous biotite schists and fine-grained muscovite metarenites, with centimeter-thick quartzite and calc-silicate intercalations. The schists present brownish coloration and lepidoblastic texture, defined by the orientation of biotite and muscovite.

The intrusive character of the stocks is marked by gradual contacts with schists, where the mafic magmas intrude the host rocks and promote the formation of migmatitic-like structures, with varying degrees of partial melting. The presence of abundant metasedimentary xenoliths and centimeter-thick granite apophyses in the host rocks reinforces the intrusive character of these bodies.

The studied igneous rocks are deformed, showing a well-defined foliation marked by biotite, amphibole, and feldspar, as well as by the major axis of xenoliths and enclaves. The elongated shape of the bodies, associated with the presence of flat-lying foliation parallel to the host rocks orientation, suggests an early to syn-collisional emplacement of these intrusions, similar to other plutons identified in the SOS (Bueno et al. 2009, Oliveira et al. 2015a) and PEAL (Silva Filho et al. 2016).

\section{Capela stock}

The Capela stock $\left(20 \mathrm{~km}^{2}\right.$; Fig. 2$)$ has an elongated NW-SE ellipsoidal shape. It is bounded to the north by the Capela fault, which is subsidiary to São Miguel do Aleixo shear zone (Fig. 2). In the proximity of the shear zone, gabbroic rocks exhibit S/C structures and rotated ultramafic blocks indicating sinistral kinematics.

The Capela stock is essentially constituted of biotite-hornblende quartz diorites, biotite-hornblende quartz gabbros, and biotite hornblendites (Fig. 3A), with minor biotite-hornblende gabbronorites. These rocks are dark grey to black colored and exhibit a fine- to medium-grained equigranular texture. Some hornblendites are porphyritic, displaying amphibole phenocrysts about $2.0 \mathrm{~cm}$, immersed in a medium-grained matrix. Biotite-bearing or two-mica leucogranites may be locally found. These felsic granitoids occur as large outcrops, isolated dikes or dike swarms. In the first case, the contact between the granites and the mafic-ultramafic members cannot be observed in field. The granites are grey or brown colored, medium-grained with equigranular to inequigranular texture, sometimes showing K-feldspar crystals with up to $1.0 \mathrm{~cm}$.

The diorites and hornblendites (Fig. 3B) consist of hornblende, plagioclase, and biotite, with subordinate microline, quartz and clinopyroxene relicts preserved into amphibole crystals. Accessory minerals are titanite, epidote, allanite, apatite, zircon, pyrite, and ilmenite. The gabbros present similar mineralogy, differing only in the content of anorthite in plagioclase, the higher volume of augite-diopside and the presence of enstatite (Pereira et al. 2019). Garnet crystals with up to $0.4 \mathrm{~cm}$ occur as disseminated grains or in aggregates in diorites and hornblendites. The quartz displays undulose extinction and chessboard subgrains texture (Fig. 3C).

Secondary minerals include tremolite-actinolite formed from amphibole and saussurite from plagioclase. Biotite is replaced by chlorite/muscovite along to cleavage planes and sometimes exsolve fine needle-like rutile grains.

Microgranular mafic enclaves (MME) and cumulate hornblendite enclaves (CHE) are common. They have rounded, ellipsoidal or lenticular shapes and sizes ranging from 5 to $70 \mathrm{~cm}$. MME correspond to dark grey quartz dioritic fine-grained rocks composed of plagioclase, quartz, biotite, and amphibole. They show sharp or gradual contacts with the host rocks, have feldspar inclusions and, sometimes, exhibit thin biotite-rich reaction edges. Centimetric biotitic schlieren is common in the MME-rich zones. The $\mathrm{CHE}$ are of greenish coloration, and coarse-grained equigranular or porphyritic textures; their contacts with the host rocks are sharp. Pereira et al. (2019) interpret the CHE as reworked early cumulates.

\section{Dores stock}

The Dores stock $\left(5 \mathrm{~km}^{2}\right)$ corresponds to an NW-SE elongated strip which outcrops in Nossa Senhora das Dores region (Fig. 2). It is constituted of grey hornblende-biotite quartz diorites, which are occasionally garnet-rich (Fig. 3D). These rocks are mesocratic to melanocratic, equigranular and fine- to medium-grained. They are composed of plagioclase, biotite, hornblende, diopside, and garnet, besides accessory phases such as epidote, titanite, apatite, zircon, and opaque minerals. Plagioclase occurs as hipidiomorphic zoned crystals. Reddish-brown subhedral biotite generally occurs in hornblende, diopside, titanite, and epidote aggregates (Fig. 3E). Some biotite crystals can show undulose extinction and kink folds. Green hornblende is subhedral and exhibits simple or lamellar twinnings. Diopside occurs as relicts inside hornblende. Quartz crystals are anhedral and interstitial, locally occurring with subgrains and as polygonal aggregates with strong undulose extinction. Garnet is found as disseminated subhedral and anhedral crystals (Fig. 3F). Titanite crystals 
are subhedral and exhibit well-developed lamellar twinning. Euhedral magmatic epidote can be identified in aggregates with mafic minerals or enclosed by biotite. Apatite exhibits acicular habit.

\section{Aquidabã stock}

The Aquidabã stock ( $5 \mathrm{~km}^{2}$, Fig. 2$)$ has NE-SW elongated ellipsoidal shape and is constituted of hornblende-biotite quartz gabbros. These rocks are dark-colored, exhibit fine to medium granulation and equigranular texture rocks (Fig. 3G). Their mineralogy comprises plagioclase, biotite, hornblende, diopside, and quartz, with opaque minerals, apatite, and zircon accessory minerals.

Plagioclase is subhedral and presents albite and albite-Carlsbad twinnings. Some crystals present patchy zoning characterized by corroded calcic cores surrounded by sodic plagioclase. The boundary between zones is usually marked by apatite and biotite inclusion trails (Fig. $3 \mathrm{H}$ ). Occasionally kink-folded plagioclase crystals are observed. Amphibole crystals exhibit compositional zoning, with brownish cores and green borders, simple or lamellar twinning and usually occur in aggregates with biotite. The amphibole is replaced by biotite, mainly across the cleavage plans (Fig. 3I). Biotite is anhedral, with exsolved needles of sagenitic rutile and is replaced by chlorite. Quartz is interstitial with strong undulose extinction. The largest crystals generally contain subgrains while the smallest ones tend to occur as polygonal grain aggregates. Opaque minerals crystals are hypidiomorphic and show square or tabular grains included in biotite and amphibole crystals.

\section{Camará association}

The Camará association consists of the Campo Grande $\left(4 \mathrm{~km}^{2}\right)$, Camará $\left(10 \mathrm{~km}^{2}\right)$, and Pedra Branca $\left(1 \mathrm{~km}^{2}\right)$ stocks, which outcrop in the boundaries of the Itabi town (Fig. 2). The most important intrusion of this group is the Camará stock, which has a U-Pb SHRIMP zircon age of $628 \pm 12 \mathrm{Ma}$ (Bueno et al. 2009).

These bodies present a rounded to elliptical geometry and consist of biotite-hornblende quartz diorites (Fig. 3J), with subordinate biotite-hornblende quartz gabbro and biotite

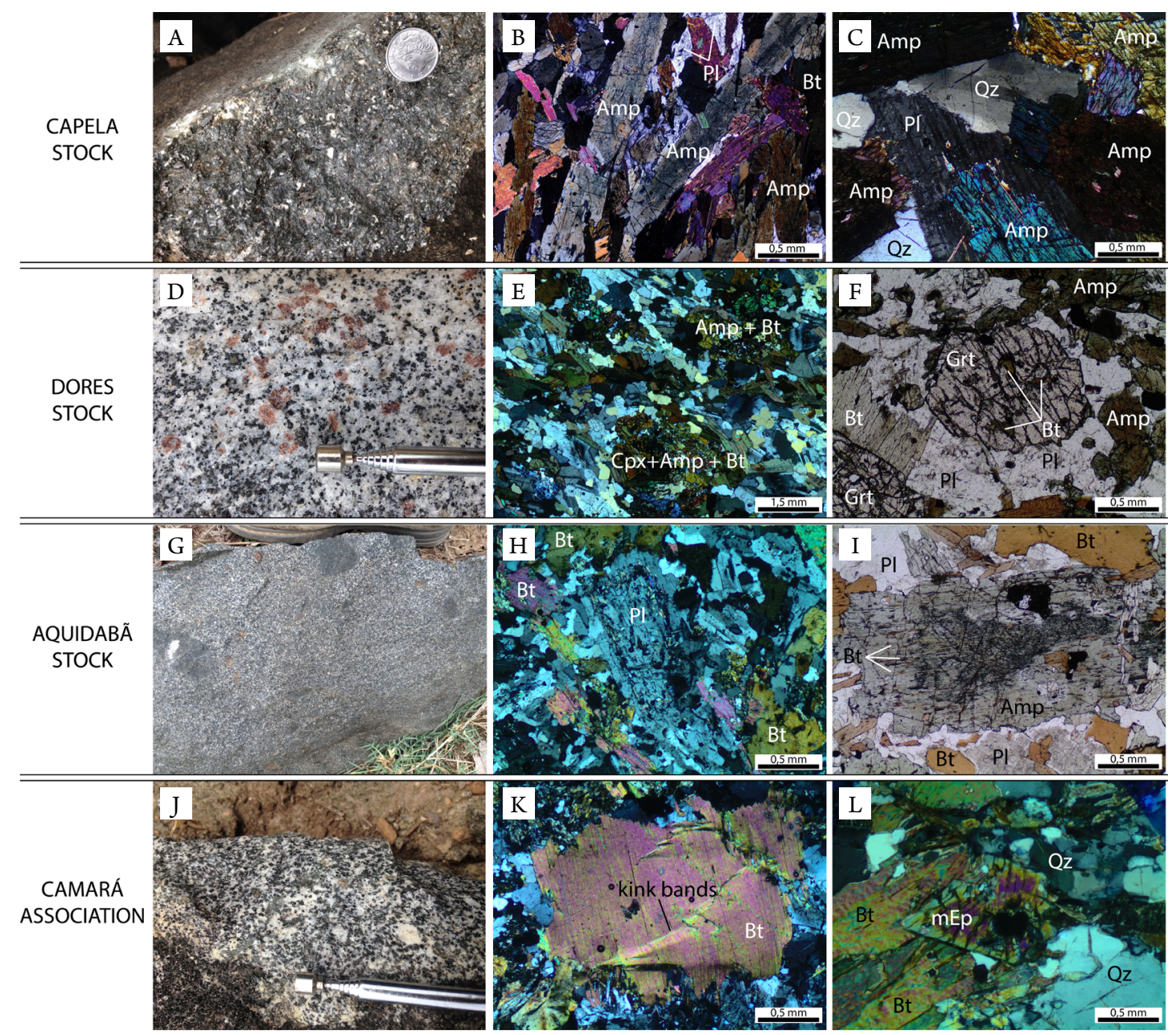

Amp: amphibole; Bt: biotite; Cpx: clinopyroxene; Grt: garnet; mEp: magmatic epidote; Pl: plagioclase; Qz: quartz.

Figure 3. Field and petrographic aspects. (A) Macroscopic texture of plagioclase-bearing biotite hornblendite. (B) Cumulate texture in hornblendite, with plagioclase into interstices between amphibole and biotite crystals. (C) Chessboard subgrains texture in quartz. (D) Equigranular garnet-bearing hornblende-biotite quartz diorite. (E) Mafic clots composed of biotite, amphibole, and clinopyroxene. (F) Subhedral garnet showing inclusions of biotite. (G) Equigranular biotite-hornblende quartz gabbro. (H) Plagioclase displaying inclusion trails between different zones. (I) Secondary substitution of hornblende by biotite along to cleavage planes. (J) Inequigranular biotitehornblende quartz diorite. (K) Biotite crystal with kink bands. (L) Subhedral magmatic epidote with allanite core, partially reabsorbed in contact zone with quartz. 
granodiorites. These rocks are dark grey to black, have medium granulation and equigranular or inequigranular texture, showing plagioclase and microcline crystals of up to $1.0 \mathrm{~cm}$ in size. The mineralogy is mainly composed of plagioclase, biotite, and hornblende, with smaller amounts of quartz, microcline, and diopside. The common accessory minerals are epidote, titanite, allanite, apatite, zircon and opaque minerals.

Plagioclase is hypidiomorphic, zoned, with kink folds. Biotite is reddish-brown, anhedral, and exhibits undulose extinction and kink bands (Fig. 3K). Hornblende has a subhedral, zoned and occurs dispersed or in aggregates with biotite and epidote. Diopside occurs mainly as relicts in hornblende nuclei. Quartz is interstitial with pronounced undulose extinction. In some samples, quartz is stretched and recrystallized in ribbons, which are oriented parallel to a high-dip mylonitic foliation. The crystals contain subgrains but locally form polygonal aggregates. In the granodiorites, microcline crystals are perthitic and present multiple compositional zoning. Magmatic epidote is common, especially in the Pedra Branca stock, forming euhedral to subhedral zoned crystals that are enclosed in biotite, with or without metamict allanite cores (Fig. 3L). Some epidote grains present corroded edges in contact with felsic minerals. Apatite often has an acicular habit. Zircon and allanite present concentric zoning.

Microgranular dioritic and gabbroic enclaves (MME) and metasedimentary xenoliths are common, especially in the Camará stock, where these structures are deformed along with their host mafic rocks.

\section{U-PB SHRIMP GEOCHRONOLOGY}

Representative samples of the Capela (SOS 696F), Aquidabã (SOS 700), and Campo Grande (SOS 624) stocks were selected for $\mathrm{U}-\mathrm{Pb}$ dating. Zircon grains used for geochronological analyses were concentrated by conventional techniques of crushing, grinding, and screening in a Wilfley table and dense liquids. The crystals were manually selected, mounted in epoxy resin along with the TEMORA 2 reference zircon and polished until the cores were exposed. The grains were photographed in reflected and transmitted light. They were coated with gold and imaged by cathodoluminescence (Fig. 4) so that the internal structures could be investigated, facilitating the selection of crystals and zones to be analyzed.

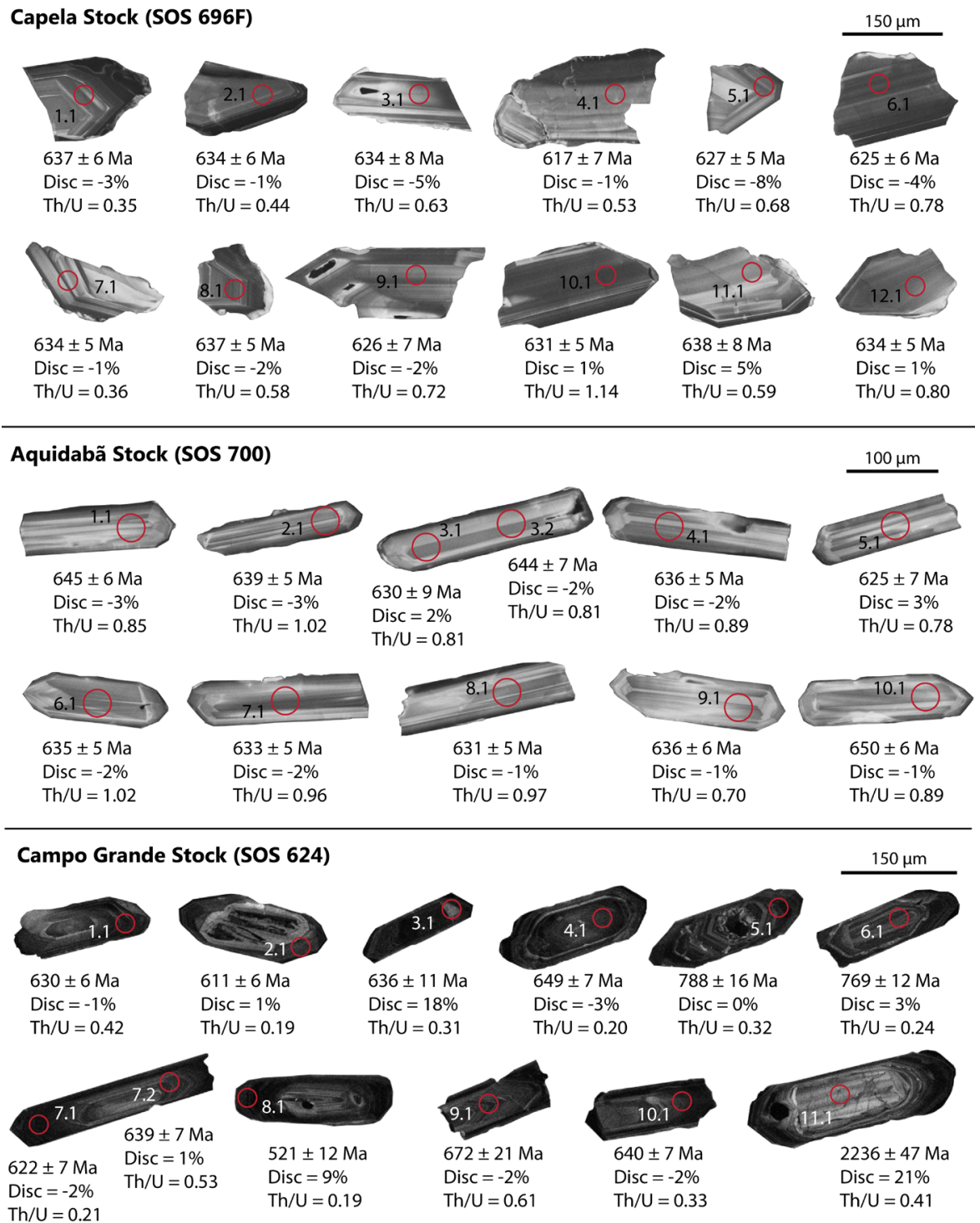

Figure 4. Cathodoluminescence images and ${ }^{206} \mathrm{~Pb} /{ }^{238} \mathrm{U}$ ages for analyzed zircon crystals from Capela, Aquidabã and Campo Grande stocks. Red circles indicate the spot location and have about $30 \mu \mathrm{m}$. 
The SHRIMP IIe/MC (Sensitive High Resolution Ion Microprobe) from the High Resolution Geochronology Laboratory of the University of São Paulo was used to dose the U-Th-Pb isotopic ratios of zircon crystals. Uranium concentrations were determined based on SL13 zircon (238 ppm; Williams 1997) and the $\mathrm{U} / \mathrm{Pb}$ ratios were normalized in relation to the reference age equivalent value or TEMORA 2 zircon (416.8 $\pm 0.2 \mathrm{Ma}$; Black et al. 2004). The analytical procedures are detailed in Sato et al. (2014).

The reduction of raw isotopic data was performed by the SQUID program (Ludwig 2009a). Uncertainty in individual analysis in the data table is reported at $1 \sigma$ level (Tab. 1). Of the selected spots, only the ones with a degree of discordance lesser than 5\% were used to calculate the age. Concordia diagrams were made by using Isoplot/Excel software (Ludwig 2009b), with error ellipses reflecting $2 \sigma$ of uncertainty.

\section{Capela age}

The zircons analyzed were obtained from biotite hornblendite with plagioclase (SOS 696F) collected from a quarry located on the northern edge of the Capela stock (37०04’07”W/10²6’28”S). Twelve zircon crystals were analyzed, comprising twelve spots. The results of the analysis are presented in Table 1.

The crystals analyzed are pale brown to colorless. They are anhedral and occasionally exhibit subhedral prismatic forms, with pyramidal endings (Fig. 4). The sizes range from 114 to $302 \mu \mathrm{m}$, with length/width ratios ranging from $1: 1$ to $3: 1$. All crystals show oscillatory zoning and varying Th/U ratios from 0.35 to 1.14 , typical features of magmatic zircons (Williams \& Claesson 1987, Corfu et al. 2003).

A set of eleven spots provided a Concordia age of $631 \pm 3 \mathrm{Ma}$ (MSWD = 1.8; Fig. 5A), which is interpreted as the crystallization age of the Capela stock.

\section{Aquidabã age}

The sample selected corresponds to an equigranular biotite-hornblende gabbro (SOS 700), collected at the edge of the Aquidabã stock ( $\left.37^{\circ} 01^{\prime} 23^{\prime \prime} \mathrm{W} / 10^{\circ} 15^{\prime} 30^{\prime \prime} \mathrm{S}\right)$. Ten zircon crystals were analyzed, totaling eleven spots. The results are shown in Table 1.

The zircon crystals are pale brown to colorless and free of inclusions or fractures. They exhibit euhedral and subhedral prismatic forms, with usually elongated and bipyramidal types (Fig. 4). Sizes vary from 152 to $220 \mu \mathrm{m}$, while the length/width ratios range from 3:1 to 5:1. All crystals exhibit cathodoluminescence oscillatory zoning and $\mathrm{Th} / \mathrm{U}$ ratios between 0.70 and 1.02, which are typical of magmatic zircons (Williams \& Claesson 1987). Inherited cores and overgrowths were not identified.

The eleven concordant analyses define a Concordia age of $636 \pm 4 \mathrm{Ma}(\mathrm{MSWD}=0.80$; Fig. $5 \mathrm{~B})$, which is interpreted as the crystallization age of the Aquidabã stock.

\section{Campo Grande age}

The sample corresponds to an equigranular biotite quartz monzodiorite (SOS 624), collected in the central portion of the stock (37008'19”W/1004'29”S). Eleven zircon crystals were analyzed, totaling twelve spots. Isotopic $\mathrm{U}-\mathrm{Pb}$ data are shown in Table 1.

The dated grains are pale pink to colorless, contain rare inclusions and are fracture-free. They are usually euhedral, with elongated prismatic forms and bipyramidal endings (Fig. 4). Sizes range from 141 to $279 \mu \mathrm{m}$, with length/width ratios ranging between $2: 1$ and 5:1. The crystals display oscillatory zoning in cathodoluminescence images and $\mathrm{Th} / \mathrm{U}$ ratios vary from 0.19 to 0.61 , marking their magmatic character (Williams \& Claesson 1987).

Except for three spots $(3.1,8.1,11.1)$, the analyzed zircons have concordant ${ }^{206} \mathrm{~Pb} /{ }^{238} \mathrm{U}$ and ${ }^{207} \mathrm{~Pb} /{ }^{206} \mathrm{~Pb}$ ages. A set of seven data defines a Concordia age of $629 \pm 9 \mathrm{Ma}(\mathrm{MSWD}=0.013$; Fig. 5C), which is interpreted as the crystallization age of the Campo Grande stock.

The presence of crystals with inherited core is common. Some cores are homogeneous and non-zoned, while others exhibit oscillatory zoning. The core-rim limit is frequently irregular and marked by a thin bright zone in cathodoluminescence images. The ${ }^{206} \mathrm{~Pb} /{ }^{238} \mathrm{U}$ subconcordant 788 and $769 \mathrm{Ma}$, and discordant $2236 \mathrm{Ma}$ ages were obtained in three inherited cores $(5.1,6.1,11.1)$. Igneous rocks of these ages are not registered in the Macururé Domain. However, Paleoproterozoic and Tonian ages like those obtained in this study are reported in metasedimentary rocks from SOS (Oliveira et al. 2015b, Neves et al.2016) and PEAL (Silva Filho et al.2014). Igneous rocks with crystallization age around $700 \mathrm{Ma}$ in SOS are recognized only in the Canindé Domain (Oliveira et al. 2010).

\section{GEOCHEMISTRY}

Whole-rock geochemical data were obtained for 66 samples of six mafic stocks. Major elements were dosed in pressed pellets at the Laboratório de Geociências da Universidade Federal de Sergipe (CLGeo-UFS) using a Shimadzu XRF$1800 \mathrm{X}$-ray fluorescence. The pellets were prepared by mixing the pulverized samples and boric acid in a 3:1 proportion (3 parts of samples to 1 of acid), whose mixture was then pressed into a hydraulic press. Certified reference materials (e.g. AVG-1, DTS-1, QLO-1) were prepared using the same procedure to monitor analytical precision. The analytical precision is generally better than $0.5 \mathrm{wt} . \%$ for all elements. Three samples were analyzed in duplicate aiming to monitor the accuracy of the measures. The discrepancy among duplicates is less than $0.5 \mathrm{wt}$.\%. To determine loss on ignition, the samples were heated at a constant temperature of $1,000^{\circ} \mathrm{C}$ in a muffle furnace for $2 \mathrm{~h}$.

Trace elements were analyzed by Inductively Coupled Plasma Mass Spectrometry (ICP-MS) at the ALS Laboratories in the United States. Chemical data of representative samples are listed in Table 2. Geochemical diagrams were drawn by using of Geochemical Data Toolkit (GCDkit) (Janoušek et al. 2006).

Most of the rocks show their original igneous textures; however, they were subjected to varying degrees of deformation and weathering, evidenced mainly by transformations of the primary paragenesis. Thus, the evaluation of the mobility 
of elements is necessary before performing interferences on the petrogenesis of these rocks.

The values of the chemical index of alteration $(\mathrm{CIA}=$ molecular $\left.\left[\mathrm{Al}_{2} \mathrm{O}_{3} / \mathrm{Al}_{2} \mathrm{O}_{3}+\mathrm{CaO}+\mathrm{Na}_{2} \mathrm{O}+\mathrm{K}_{2} \mathrm{O}\right] \times 100\right)$ range between 27 (hornblendite) and 55 (granite), similar to those reported by Nesbitt and Young (1982) for basic igneous rocks and non-weathered acidic ones. Low loss on ignition values (LOI $<1.7$ wt.\%) indicate none or incipient hydrothermal

Table 1. SHRIMP U-Pb zircon data from Capela, Aquidabã, and Campo Grande stocks.

\begin{tabular}{|c|c|c|c|c|c|c|c|c|c|c|c|c|c|c|}
\hline \multirow[b]{2}{*}{$\begin{array}{l}\text { ID } \\
\text { Spot }\end{array}$} & \multirow[b]{2}{*}{$\%^{206} \mathbf{P b}^{\mathrm{a}}$} & \multirow{2}{*}{$\begin{array}{c}\mathbf{U} \\
(\mathbf{p p m})\end{array}$} & \multirow[b]{2}{*}{$\begin{array}{c}\text { Th } \\
(\mathbf{p p m})\end{array}$} & \multirow[b]{2}{*}{${ }^{232} \mathrm{Th} /{ }^{238} \mathbf{U}^{\mathrm{b}}$} & \multicolumn{7}{|c|}{ Isotope ratios $^{c}$} & \multicolumn{3}{|c|}{ Ages (Ma) } \\
\hline & & & & & ${ }^{207} \mathrm{~Pb} /{ }^{206} \mathrm{~Pb}$ & $\begin{array}{l}1 \sigma \\
(\%)\end{array}$ & ${ }^{207} \mathbf{P b} /{ }^{235} \mathbf{U}$ & $\begin{array}{l}1 \sigma \\
(\%)\end{array}$ & ${ }^{206} \mathrm{~Pb} /{ }^{238} \mathrm{U}$ & $\begin{array}{l}1 \sigma \\
(\%)\end{array}$ & Rho ${ }^{d}$ & $\begin{array}{c}{ }^{206} \mathrm{~Pb} /{ }^{238} \mathrm{U} \\
(1 \sigma)\end{array}$ & $\begin{array}{c}{ }^{207} \mathbf{P b} /{ }^{206} \mathbf{P b} \\
(1 \sigma)\end{array}$ & \%Disc ${ }^{\mathrm{e}}$ \\
\hline \multicolumn{15}{|c|}{ Capela stock } \\
\hline 1.1 & 0.03 & 677 & 231 & 0.35 & 0.06044 & 0.9 & 0.86570 & 1.3 & 0.10388 & 1.0 & 0.735 & $637 \pm 6$ & $619 \pm 19$ & -3 \\
\hline 2.1 & 0.00 & 353 & 150 & 0.44 & 0.06063 & 0.7 & 0.86454 & 1.3 & 0.10342 & 1.0 & 0.823 & $634 \pm 6$ & $626 \pm 15$ & -1 \\
\hline 3.1 & 0.03 & 147 & 90 & 0.63 & 0.06007 & 1.2 & 0.85572 & 1.7 & 0.10332 & 1.3 & 0.734 & $634 \pm 8$ & $606 \pm 26$ & -5 \\
\hline 4.1 & 0.12 & 308 & 157 & 0.53 & 0.06019 & 1.0 & 0.83352 & 1.6 & 0.10044 & 1.2 & 0.783 & $617 \pm 7$ & $610 \pm 21$ & -1 \\
\hline $5.1^{+}$ & 0.04 & 236 & 155 & 0.68 & 0.05940 & 0.9 & 0.83701 & 1.2 & 0.10220 & 0.8 & 0.678 & $627 \pm 5$ & $582 \pm 20$ & -8 \\
\hline 6.1 & 0.00 & 418 & 314 & 0.78 & 0.05993 & 0.7 & 0.84057 & 1.2 & 0.10173 & 1.0 & 0.839 & $625 \pm 6$ & $601 \pm 14$ & -4 \\
\hline 7.1 & 0.05 & 198 & 69 & 0.36 & 0.06068 & 1.1 & 0.86526 & 1.4 & 0.10342 & 0.9 & 0.635 & $634 \pm 5$ & $628 \pm 23$ & -1 \\
\hline 8.1 & 0.04 & 397 & 221 & 0.58 & 0.06059 & 0.7 & 0.86709 & 1.1 & 0.10380 & 0.8 & 0.743 & $637 \pm 5$ & $625 \pm 16$ & -2 \\
\hline 9.1 & 0.06 & 221 & 154 & 0.72 & 0.06029 & 1.0 & 0.84742 & 1.5 & 0.10194 & 1.2 & 0.748 & $626 \pm 7$ & $614 \pm 22$ & -2 \\
\hline 10.1 & 0.04 & 491 & 544 & 1.14 & 0.06095 & 0.6 & 0.86434 & 1.0 & 0.10284 & 0.8 & 0.785 & $631 \pm 5$ & $638 \pm 14$ & 1 \\
\hline 11.1 & 0.03 & 170 & 97 & 0.59 & 0.06189 & 1.1 & 0.88786 & 1.7 & 0.10404 & 1.3 & 0.755 & $638 \pm 8$ & $670 \pm 24$ & 5 \\
\hline 12.1 & 0.03 & 281 & 219 & 0.80 & 0.06100 & 0.9 & 0.86949 & 1.2 & 0.10338 & 0.8 & 0.695 & $634 \pm 5$ & $639 \pm 19$ & 1 \\
\hline \multicolumn{15}{|c|}{ Aquidabã stock } \\
\hline 1.1 & 0.07 & 124 & 102 & 0.85 & 0.06066 & 1.3 & 0.87963 & 1.6 & 0.10518 & 1.0 & 0.586 & $645 \pm 6$ & $627 \pm 28$ & -3 \\
\hline 2.1 & 0.02 & 204 & 201 & 1.02 & 0.06054 & 0.9 & 0.86972 & 1.3 & 0.10419 & 0.9 & 0.672 & $639 \pm 5$ & $623 \pm 20$ & -3 \\
\hline 3.1 & 0.04 & 103 & 80 & 0.81 & 0.06107 & 1.4 & 0.86382 & 2.0 & 0.10258 & 1.4 & 0.722 & $630 \pm 9$ & $642 \pm 29$ & 2 \\
\hline 3.2 & 0.07 & 120 & 95 & 0.81 & 0.06082 & 2.0 & 0.88101 & 2.4 & 0.10506 & 1.2 & 0.494 & $644 \pm 7$ & $633 \pm 44$ & -2 \\
\hline 4.1 & 0.10 & 143 & 124 & 0.89 & 0.06063 & 1.3 & 0.86710 & 1.6 & 0.10373 & 0.9 & 0.560 & $636 \pm 5$ & $626 \pm 29$ & -2 \\
\hline 5.1 & 0.09 & 101 & 77 & 0.78 & 0.06108 & 1.6 & 0.85720 & 2.0 & 0.10179 & 1.2 & 0.610 & $625 \pm 7$ & $642 \pm 34$ & 3 \\
\hline 6.1 & 0.06 & 215 & 211 & 1.02 & 0.06061 & 1.0 & 0.86537 & 1.3 & 0.10356 & 0.9 & 0.652 & $635 \pm 5$ & $625 \pm 21$ & -2 \\
\hline 7.1 & 0.10 & 196 & 183 & 0.96 & 0.06052 & 1.2 & 0.86048 & 1.5 & 0.10312 & 0.9 & 0.592 & $633 \pm 5$ & $622 \pm 26$ & -2 \\
\hline 8.1 & 0.09 & 157 & 147 & 0.97 & 0.06069 & 1.3 & 0.86100 & 1.6 & 0.10289 & 0.9 & 0.571 & $631 \pm 5$ & $628 \pm 27$ & -1 \\
\hline 9.1 & 0.13 & 70 & 48 & 0.70 & 0.06065 & 2.0 & 0.86344 & 2.2 & 0.10325 & 1.0 & 0.460 & $633 \pm 6$ & $627 \pm 43$ & -1 \\
\hline 10.1 & 0.04 & 112 & 96 & 0.89 & 0.06116 & 2.1 & 0.89487 & 2.3 & 0.10612 & 1.0 & 0.423 & $650 \pm 6$ & $645 \pm 46$ & -1 \\
\hline \multicolumn{15}{|c|}{ Campo Grande stock } \\
\hline 1.1 & 0.14 & 573 & 231 & 0.42 & 0.06053 & 1.8 & 0.85672 & 2.1 & 0.10266 & 1.1 & 0.515 & $630 \pm 6$ & $622 \pm 39$ & -1 \\
\hline 2.1 & 0.94 & 320 & 58 & 0.19 & 0.06030 & 2.9 & 0.82719 & 3.1 & 0.09949 & 1.0 & 0.318 & $611 \pm 6$ & $614 \pm 63$ & 1 \\
\hline $3.1^{+}$ & 0.50 & 1097 & 328 & 0.31 & 0.06115 & 0.9 & 0.73117 & 2.3 & 0.08672 & 2.1 & 0.918 & $536 \pm 11$ & $644 \pm 20$ & 18 \\
\hline 4.1 & 0.03 & 1029 & 195 & 0.20 & 0.06081 & 0.7 & 0.88809 & 1.3 & 0.10593 & 1.1 & 0.843 & $649 \pm 7$ & $632 \pm 15$ & -3 \\
\hline $5.1^{+}$ & 0.34 & 669 & 210 & 0.32 & 0.06535 & 1.1 & 1.17154 & 2.5 & 0.13002 & 2.2 & 0.894 & $788 \pm 16$ & $786 \pm 23$ & 0 \\
\hline $6.1^{+}$ & 0.14 & 387 & 90 & 0.24 & 0.06560 & 1.0 & 1.14537 & 1.9 & 0.12664 & 1.6 & 0.846 & $769 \pm 12$ & $794 \pm 22$ & 3 \\
\hline 7.1 & 0.01 & 2595 & 526 & 0.21 & 0.06023 & 0.4 & 0.84084 & 1.2 & 0.10126 & 1.1 & 0.932 & $622 \pm 7$ & $612 \pm 9$ & -2 \\
\hline 7.2 & 0.06 & 443 & 225 & 0.53 & 0.06108 & 1.1 & 0.87712 & 1.6 & 0.10415 & 1.1 & 0.716 & $639 \pm 7$ & $642 \pm 24$ & 1 \\
\hline $8.1^{+}$ & 0.34 & 2248 & 418 & 0.19 & 0.05907 & 1.1 & 0.68542 & 2.0 & 0.08415 & 1.7 & 0.835 & $521 \pm 8$ & $570 \pm 24$ & 9 \\
\hline 9.1 & 0.12 & 476 & 283 & 0.61 & 0.06158 & 1.2 & 0.93284 & 3.6 & 0.10986 & 3.3 & 0.939 & $672 \pm 21$ & $660 \pm 26$ & -2 \\
\hline 10.1 & 0.05 & 596 & 188 & 0.33 & 0.06066 & 0.9 & 0.87327 & 1.4 & 0.10441 & 1.1 & 0.796 & $640 \pm 7$ & $627 \pm 18$ & -2 \\
\hline $11.1^{+}$ & 6.52 & 176 & 70 & 0.41 & 0.18801 & 0.9 & 10.74883 & 2.6 & 0.41466 & 2.5 & 0.946 & $2,236 \pm 47$ & $2,725 \pm 14$ & 21 \\
\hline
\end{tabular}

${ }^{a}$ Percentage of non-radiogenic ${ }^{206} \mathrm{~Pb}$ in the analyzed zircon spot, where $\%{ }^{206} \mathrm{~Pb}=100 \times\left({ }^{206} \mathrm{~Pb} /{ }^{204} \mathrm{~Pb}\right) \mathrm{c} /\left({ }^{206} \mathrm{~Pb} /{ }^{204} \mathrm{~Pb}\right) \mathrm{s}(\mathrm{c}=$ common; $\mathrm{s}=$ sample $)$; ${ }^{\mathrm{b}} \mathrm{Th} / \mathrm{U}$ ratio and concentration of $\mathrm{U}, \mathrm{Th}$ and $\mathrm{Pb}$ are calculated relative to the SL13 reference zircon; cisotope ratios corrected for mass-bias by normalizing to TEMORA 2 reference zircon and common $\mathrm{Pb}$ corrected by using the model of Stacey and Kramers (1975); ${ }^{\mathrm{d}}$ error correlation defined as the quotient of the propagated errors of ${ }^{206} \mathrm{~Pb} /{ }^{238} \mathrm{U}$ and ${ }^{207} \mathrm{~Pb} /{ }^{235} \mathrm{U}$ ratios; ${ }^{e}$ degree of discordance $=100 \times\left[1-\left({ }^{206} \mathrm{~Pb} /{ }^{238} \mathrm{U}\right.\right.$ age $) /\left({ }^{207} \mathrm{~Pb} /{ }^{206} \mathrm{~Pb}\right.$ age $\left.)\right]$; ${ }^{+}$rejected analyses from the age calculations. 
alteration. Absence of significant cerium anomalies $\left(\mathrm{Ce} / \mathrm{Ce}^{*}\right.$ $=0.87-1.21)$ in relation to $\mathrm{La}$ and $\operatorname{Pr}(\mathrm{Tab} .2)$ indicates that any interaction that may have occurred with oxidizing fluids did not significantly affect the primary compositions of the rocks. Therefore, the abundance of these elements can be used to evaluate the petrogenesis of rocks.

The hornblendites, gabbros, and diorites have $\mathrm{SiO}_{2}$ contents ranging from 40.2 to $61.8 \%$, with magnesium number
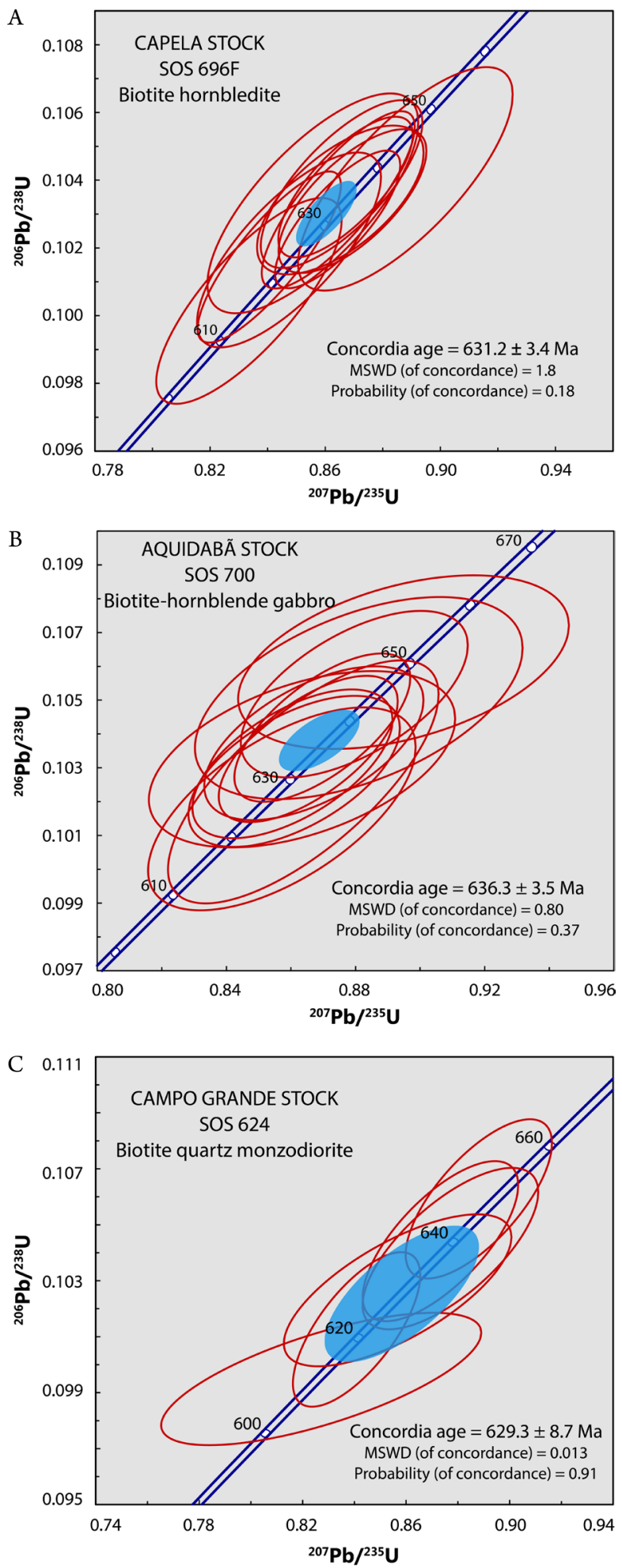

Figure 5. Concordia diagrams showing the $\mathrm{U}-\mathrm{Pb}$ ages for Capela (A), Aquidabã (B), and Campo Grande (C) stocks.
$(\mathrm{Mg} \#=\mathrm{MgO} /[\mathrm{MgO}+\mathrm{FeOt}])$ between 0.41 and 0.65 . The highest contents of $\mathrm{Al}_{2} \mathrm{O}_{3}$ (9.23-19.40 wt.\%), $\mathrm{CaO}$ (5.5012.26 wt.\%), $\mathrm{MgO}$ (5.16-12.99 wt.\%), and $\mathrm{Fe}_{2} \mathrm{O}_{3}$ (12.17$19.37 \mathrm{wt} . \%$ ) occur in these rocks. They are metaluminous (A/ $\mathrm{CNK}=0.37-0.98)$ except for garnet-rich diorites from Capela stock, which are weakly peraluminous $(\mathrm{A} / \mathrm{CNK}=1.02-1.03)$, with normative corundum reaching $2.5 \%$.

The felsic granitoids have $\mathrm{SiO}_{2}$ ranging from 62.7 to 70.5 wt.\% and $\mathrm{K}_{2} \mathrm{O}$ from 2.20 to 5.32 wt.\%, with $\mathrm{K}_{2} \mathrm{O} / \mathrm{Na}_{2} \mathrm{O}$ ratios between 0.61 and 1.51 . They are metaluminous to weakly peraluminous, with $\mathrm{A} / \mathrm{CNK}$ index ranging from 0.89 to 1.08 .

Most samples have a transitional character between the subalkaline and alkaline series in the total alkalis versus silica diagram (Fig. 6A). Among the primitive members, gabbros and diorites compositions are dominant. The hornblendite of the Capela stock plot within the alkali gabbro and foidolite fields. MME are gabbroic, dioritic, and monzodioritic in composition, whereas the $\mathrm{CHE}$ are essentially gabbroic. Compositions of felsic rocks are allocated within the fields of the granodiorite, quartz monzonite, and granite.

In the modified alkali-lime index (MALI) diagram (Frost et al.2001), most samples plot mainly in the calc-alkaline and alkali-calcic fields (Fig. 6C). The low FeOt / (FeOt $+\mathrm{MgO})$ values (0.55-0.68) indicate affinity with magnesian series rocks, except for three samples that trespass the ferroan series limit (Fig. 6D). In both diagrams, the compositions of the studied rocks are similar to Cordilleran granites, according to Frost et al. (2001).

When plotted in the AFM diagram, the hornblendites, gabbros, diorites, MME, and $\mathrm{CHE}$ lie in the field of mafic-ultramafic suites related to arc environments (Beard 1986; Fig. 6B). In this diagram, the data set presents a trend of alkali enrichment followed by the decrease of $\mathrm{FeOt}$ and $\mathrm{MgO}$, typical of calc-alkaline series rocks (Irvine \& Baragar 1971). According to the classification of Peccerillo and Taylor (1976), the felsic and mafic rocks are high-K calc-alkaline to shoshonitic (Fig. 7). In the $\mathrm{Na}_{2} \mathrm{O}$ versus $\mathrm{K}_{2} \mathrm{O}$ (Turner et al. 1996) and $\mathrm{Ta} / \mathrm{Yb}$ versus $\mathrm{Ce} / \mathrm{Yb}$ (Pearce 1982) diagrams, these same rocks are located in the shoshonite field (Figs. 6E and 6F). The high total alkalis $\left(\mathrm{Na}_{2} \mathrm{O}+\mathrm{K}_{2} \mathrm{O}>5\right.$ wt.\%), $\mathrm{K}_{2} \mathrm{O} / \mathrm{Na}_{2} \mathrm{O}(0.6-1.9)$ and low $\mathrm{TiO}_{2}$ $(\sim 1.1 \mathrm{wt} . \%)$ also indicate affinity with shoshonite association (Morrison 1980).

The rocks of different intrusions show coherent trends in the Harker diagrams, from hornblendites to granites (Fig. 7). Negative correlations with $\mathrm{MgO}, \mathrm{Fe}_{2} \mathrm{O}_{3}, \mathrm{CaO}, \mathrm{Na}_{2} \mathrm{O}, \mathrm{TiO}_{2}$, and $\mathrm{P}_{2} \mathrm{O}_{5}$ indicate fractionation of amphibole, pyroxene, biotite, plagioclase, $\mathrm{Fe}-\mathrm{Ti}$ oxides, and apatite.

The Macururé Mafic Suite rocks are characterized by moderate to high $\mathrm{Ba}$ (363-1,405 ppm), Rb (42-125 ppm), and Sr (144-730 ppm) contents. The Zr, Hf, Nb, and Y concentrations are low and compatible with the calc-alkaline nature of this magmatism. The transition metals contents are variable (e.g. $\mathrm{Cr}=60-870 \mathrm{ppm} ; \mathrm{V}=12-551 \mathrm{ppm}$ ), decreasing with the increase of $\mathrm{SiO}_{2}$.

The sum of rare earth elements (REE) ranges between 34 and $423 \mathrm{ppm}$, decreasing from the hornblendites, gabbros, and diorites toward the granitoids. Chondrite-normalized 
Table 2. Major and trace elements of representative samples from Dores (1), Capela (2), Aquidabã (3), Campo Grande (4), Camará (5), and Pedra Branca (6) stocks.

\begin{tabular}{|c|c|c|c|c|c|c|c|c|c|c|c|c|c|c|c|c|c|}
\hline \multirow{2}{*}{$\begin{array}{l}\text { Sample } \\
\text { Unit }\end{array}$} & \multirow{2}{*}{$\begin{array}{c}\text { AVG- } \\
1^{\mathrm{a}}\end{array}$} & \multirow{2}{*}{ \pm} & \multirow{2}{*}{$\begin{array}{c}\text { AVG- } \\
1^{\mathrm{b}}\end{array}$} & \multirow{2}{*}{ \pm} & \multirow{2}{*}{$\begin{array}{c}\text { abs } \\
\text { error }^{\mathrm{c}}\end{array}$} & \multirow{2}{*}{$\frac{910}{1}$} & \multirow{2}{*}{$\begin{array}{c}913 \\
1 \\
\end{array}$} & \multirow{2}{*}{$\begin{array}{c}696 \mathrm{~F} \\
2 \\
\end{array}$} & \multirow{2}{*}{$\frac{919 \mathrm{~B}}{2}$} & \multirow{2}{*}{$\frac{930 \mathrm{~B}}{2}$} & \multirow{2}{*}{$\begin{array}{c}940 \\
2 \\
\end{array}$} & \multirow{2}{*}{$\begin{array}{c}700 \\
3 \\
\end{array}$} & \multirow{2}{*}{$\begin{array}{c}624 \\
4 \\
\end{array}$} & \multirow{2}{*}{$\begin{array}{c}504 \mathrm{~A} \\
5\end{array}$} & \multirow{2}{*}{$\begin{array}{c}593 \\
5 \\
\end{array}$} & $591 \mathrm{~B}$ & 633 \\
\hline & & & & & & & & & & & & & & & & 5 & 6 \\
\hline Major el & lements & $(w t . \%)$ & by XRF & & & & & & & & & & & & & & \\
\hline $\mathrm{SiO}_{2}$ & 58.84 & 0.58 & 59.32 & 0.34 & 0.48 & 59.54 & 58.46 & 41.47 & 55.09 & 45.28 & 50.66 & 54.30 & 59.30 & 50.95 & 59.30 & 68.58 & 57.10 \\
\hline $\mathrm{TiO}_{2}$ & 1.05 & 0.05 & 1.05 & 0.05 & 0.00 & 0.80 & 0.81 & 2.29 & 0.62 & 1.61 & 1.35 & 1.17 & 0.72 & 1.46 & 0.88 & 0.58 & 0.80 \\
\hline $\mathrm{Al}_{2} \mathrm{O}_{3}$ & 17.15 & 0.34 & 17.61 & 0.43 & 0.46 & 15.54 & 15.61 & 13.21 & 14.13 & 12.19 & 15.50 & 15.50 & 16.90 & 18.48 & 15.06 & 14.99 & 15.05 \\
\hline $\mathrm{Fe}_{2} \mathrm{O}_{3}$ & 6.77 & 0.19 & 6.57 & 0.13 & 0.20 & 7.21 & 7.65 & 18.28 & 9.33 & 17.67 & 10.94 & 9.63 & 5.80 & 10.35 & 7.07 & 3.67 & 6.50 \\
\hline $\mathrm{MnO}$ & 0.09 & 0.006 & 0.09 & 0.008 & 0.00 & 0.08 & 0.09 & 0.16 & 0.13 & 0.18 & 0.15 & 0.12 & 0.09 & 0.13 & 0.11 & 0.04 & 0.11 \\
\hline $\mathrm{MgO}$ & 1.53 & 0.093 & 1.34 & 0.096 & 0.19 & 3.69 & 4.24 & 9.75 & 8.77 & 9.95 & 5.51 & 7.44 & 2.58 & 4.06 & 5.24 & 1.94 & 4.99 \\
\hline $\mathrm{CaO}$ & 4.94 & 0.14 & 5.07 & 0.21 & 0.13 & 5.56 & 5.40 & 10.23 & 6.68 & 8.35 & 7.12 & 5.50 & 4.92 & 6.46 & 5.05 & 3.23 & 5.00 \\
\hline $\mathrm{Na}_{2} \mathrm{O}$ & 4.26 & 0.12 & 4.13 & 0.23 & 0.13 & 2.69 & 2.70 & 1.78 & 2.08 & 1.17 & 2.48 & 2.90 & 3.78 & 3.27 & 3.05 & 3.59 & 3.26 \\
\hline $\mathrm{K}_{2} \mathrm{O}$ & 2.92 & 0.37 & 3.07 & 0.40 & 0.15 & 3.26 & 3.44 & 2.15 & 2.44 & 2.46 & 3.01 & 2.67 & 2.75 & 3.02 & 2.75 & 2.20 & 2.29 \\
\hline $\mathrm{P}_{2} \mathrm{O}_{5}$ & 0.50 & 0.03 & 0.59 & 0.06 & 0.09 & 0.33 & 0.35 & 0.70 & 0.30 & 1.19 & 0.62 & 0.36 & 0.29 & 0.55 & 0.21 & 0.17 & 0.22 \\
\hline LOI & - & - & - & - & - & 0.48 & 0.34 & 1.34 & 0.77 & 0.94 & 0.29 & 1.16 & 1.25 & - & - & - & 1.32 \\
\hline Total & 98.05 & - & 98.84 & - & - & 99.18 & 99.09 & 101.36 & 100.34 & 100.99 & 97.63 & 100.75 & 98.38 & 98.73 & 98.72 & 98.99 & 96.64 \\
\hline Trace & ements & ppm) & $y I C P$ & & & & & & & & & & & & & & \\
\hline $\mathrm{Ba}$ & & & & & & 844 & 1105 & 693 & 363 & 816 & 1145 & 642 & 1140 & 1327 & 991 & 588 & 873 \\
\hline $\mathrm{Rb}$ & & & & & & 101.5 & 99.9 & 42.6 & 64.7 & 64.4 & 73.5 & 75.9 & 99.5 & 118.8 & 92.9 & 94.6 & 81.8 \\
\hline $\mathrm{Sr}$ & & & & & & 411 & 432 & 315 & 567 & 145 & 522 & 435 & 719 & 730 & 424 & 421 & 464 \\
\hline Cs & & & & & & 3.55 & 5.43 & 2.26 & 2.47 & 1.83 & 2.89 & 4.37 & 2.76 & 3.60 & 3.70 & 3.10 & 3.78 \\
\hline $\mathrm{Ga}$ & & & & & & 25.2 & 24.1 & 24.2 & 23.2 & 26.3 & 22.6 & 23.1 & 23.2 & 26.7 & 21.0 & 19.1 & 23.4 \\
\hline $\mathrm{U}$ & & & & & & 1.81 & 1.67 & 0.67 & 1.20 & 0.89 & 1.35 & 2.06 & 2.37 & 2.30 & 1.20 & 2.70 & 1.51 \\
\hline Th & & & & & & 12.20 & 10.15 & 2.73 & 5.08 & 3.83 & 5.69 & 8.67 & 15.95 & 19.20 & 7.80 & 34.10 & 6.17 \\
\hline $\mathrm{Nb}$ & & & & & & 14.2 & 11.5 & 9.0 & 8.7 & 11.9 & 13.1 & 7.4 & 10.2 & 13.6 & 8.6 & 11.0 & 7.3 \\
\hline $\mathrm{Ta}$ & & & & & & 0.9 & 0.8 & 0.5 & 0.6 & 0.5 & 0.8 & 0.5 & 0.6 & 0.4 & 0.6 & 0.5 & 0.4 \\
\hline $\mathrm{Zr}$ & & & & & & 243 & 239 & 173 & 171 & 55 & 239 & 176 & 273 & 397 & 205 & 301 & 173 \\
\hline $\mathrm{Hf}$ & & & & & & 7.1 & 6.9 & 5.7 & 4.9 & 2.7 & 6.0 & 4.6 & 8.1 & 9.9 & 5.6 & 9.0 & 5.0 \\
\hline $\mathrm{V}$ & & & & & & 118 & 143 & 418 & 187 & 551 & 235 & 163 & 89 & 172 & 139 & 64 & 128 \\
\hline $\mathrm{Cr}$ & & & & & & 60 & 200 & 160 & 870 & 590 & 250 & 540 & 200 & - & - & - & 430 \\
\hline $\mathrm{La}$ & & & & & & 42.9 & 42.0 & 22.2 & 28.8 & 32.0 & 38.9 & 25.7 & 52.6 & 87.7 & 32.0 & 86.9 & 29.1 \\
\hline $\mathrm{Ce}$ & & & & & & 85.5 & 95.1 & 67.8 & 64.5 & 95.0 & 84.2 & 62.2 & 105.5 & 204.3 & 69.4 & 170.9 & 59.7 \\
\hline $\operatorname{Pr}$ & & & & & & 9.54 & 9.68 & 10.15 & 7.81 & 14.45 & 10.00 & 6.75 & 11.25 & 20.17 & 7.69 & 17.33 & 7.56 \\
\hline $\mathrm{Nd}$ & & & & & & 34.7 & 36.6 & 48.7 & 31.8 & 70.9 & 39.8 & 27.7 & 40.1 & 76.2 & 30.6 & 58.9 & 29.5 \\
\hline $\mathrm{Sm}$ & & & & & & 6.97 & 6.78 & 12.45 & 6.48 & 17.65 & 8.86 & 5.82 & 7.62 & 11.93 & 5.30 & 7.22 & 5.68 \\
\hline $\mathrm{Eu}$ & & & & & & 1.39 & 1.56 & 2.98 & 1.57 & 3.16 & 1.97 & 1.27 & 1.68 & 2.58 & 1.27 & 1.26 & 1.29 \\
\hline $\mathrm{Gd}$ & & & & & & 5.32 & 5.48 & 11.05 & 5.01 & 15.30 & 7.30 & 4.07 & 4.57 & 7.55 & 4.23 & 4.02 & 4.78 \\
\hline $\mathrm{Tb}$ & & & & & & 0.75 & 0.77 & 1.57 & 0.68 & 1.98 & 1.09 & 0.62 & 0.65 & 1.11 & 0.61 & 0.50 & 0.66 \\
\hline Dy & & & & & & 4.77 & 4.60 & 8.69 & 4.14 & 9.19 & 6.94 & 4.07 & 3.32 & 5.24 & 3.07 & 2.27 & 3.63 \\
\hline Ho & & & & & & 0.80 & 0.90 & 1.41 & 0.75 & 1.49 & 1.33 & 0.77 & 0.63 & 0.95 & 0.58 & 0.36 & 0.68 \\
\hline $\mathrm{Er}$ & & & & & & 1.99 & 2.33 & 3.40 & 2.17 & 3.35 & 3.41 & 2.30 & 1.72 & 2.43 & 1.55 & 1.02 & 1.75 \\
\hline $\mathrm{Tm}$ & & & & & & 0.28 & 0.32 & 0.45 & 0.30 & 0.34 & 0.53 & 0.33 & 0.23 & 0.37 & 0.24 & 0.16 & 0.26 \\
\hline $\mathrm{Yb}$ & & & & & & 1.61 & 2.16 & 2.44 & 1.99 & 1.54 & 3.24 & 1.87 & 1.45 & 2.27 & 1.52 & 1.05 & 1.49 \\
\hline $\mathrm{Lu}$ & & & & & & 0.23 & 0.30 & 0.32 & 0.26 & 0.17 & 0.42 & 0.27 & 0.21 & 0.33 & 0.22 & 0.18 & 0.22 \\
\hline $\mathrm{Y}$ & & & & & & 19.3 & 23.1 & 33.4 & 20.4 & 36.6 & 31.9 & 18.8 & 14.6 & 27.4 & 16.7 & 11.3 & 16.4 \\
\hline$\Sigma$ REE & & & & & & 196.8 & 208.6 & 193.6 & 156.3 & 266.5 & 208.0 & 143.7 & 231.5 & 423.1 & 158.3 & 352.1 & 146.3 \\
\hline $\mathrm{Eu} / \mathrm{Eu}^{* \mathrm{~d}}$ & & & & & & 0.70 & 0.79 & 0.78 & 0.85 & 0.59 & 0.75 & 0.80 & 0.88 & 0.84 & 0.82 & 0.72 & 0.76 \\
\hline $\mathrm{Ce} / \mathrm{Ce}^{* d}$ & & & & & & 0.94 & 1.05 & 1.00 & 0.96 & 0.98 & 0.95 & 1.05 & 0.96 & 1.08 & 0.98 & 0.98 & 0.89 \\
\hline$(\mathrm{Ce} / \mathrm{Yb})$ & & & & & & 13.5 & 11.2 & 7.1 & 8.2 & 15.7 & 6.6 & 8.5 & 18.5 & 22.9 & 11.6 & 41.4 & 10.2 \\
\hline
\end{tabular}

${ }^{a}$ Recommended values to the AVG-1 reference material of the U.S. Geological Survey; bobtained values for the AVG-1 reference material by using the Shimadzu XRF-1800 X-ray fluorescence spectrometer of the CLGeo-UFS; cabsolute analytical error defined as abs error (wt.\%) $=\mid$ measured value - recommended value

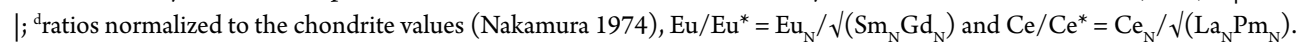


REE patterns (Nakamura 1974) of the studied samples are enriched in light rare earth elements (LREE) over heavy rare earth elements (HREE), with $\mathrm{Ce}_{\mathrm{N}} / \mathrm{Yb}_{\mathrm{N}}$ ratios ranging from 3.5 to 22.9 (Fig. 8). Discrete to pronounced negative Europium anomalies $\left(\mathrm{Eu} / \mathrm{Eu}^{*}=0.59-0.93\right)$ occur in most of samples. Only one sample from Camará stock has a positive Europium anomaly $\left(\mathrm{Eu} / \mathrm{Eu}^{*}=1.45\right)$. The REE patterns of hornblendites and gabbros from Capela stock differ from the other intrusions by the downward concave morphology and the roughly flat LREE profiles $\left(\mathrm{Ce}_{\mathrm{N}} / \mathrm{Sm}_{\mathrm{N}}=1.1-1.7\right)$.
In the multielement diagrams normalized to the chondrite values (Thompson 1982), all samples show enrichment in large ion lithophile elements (LILE) and LREE, and depletion in high field strength elements (HFSE) and HREE (Fig. 8), in addition to deep troughs in $\mathrm{Nb}$, Ta, and $\mathrm{Ti}$. The geometry of the basic and intermediate rocks spectra is similar to the primitive continental arc andesites, differing only for the higher degree of LILE enrichment in the studied rocks. The REE patterns for acidic rocks from Capela and Dores' stocks are non-parallel, sometimes showing inverse behavior with respect to the gabbros and diorites that occur associated.
A

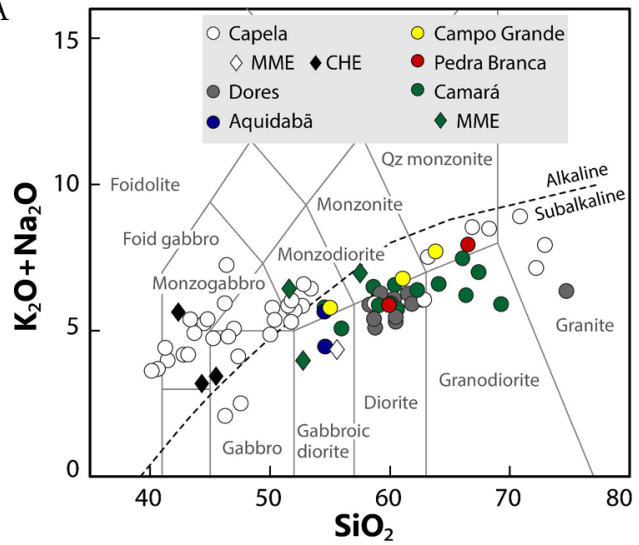

C

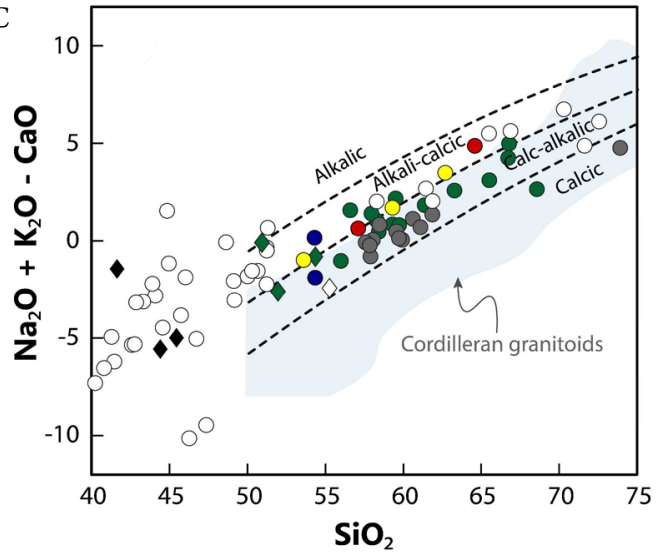

E

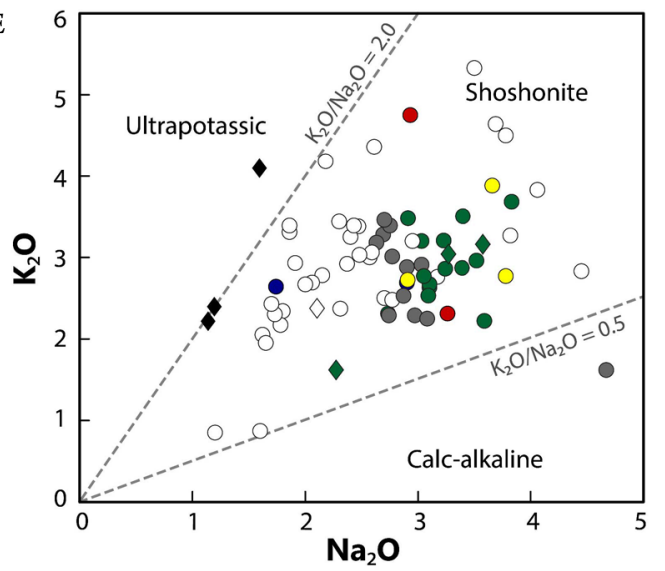

B
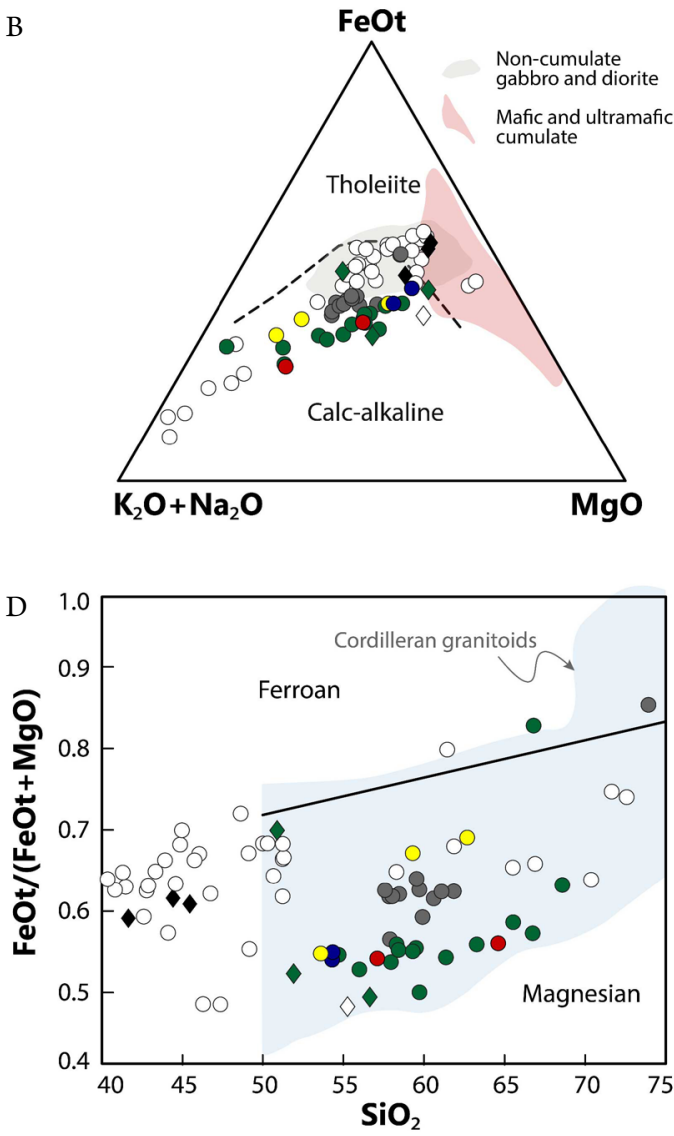

F

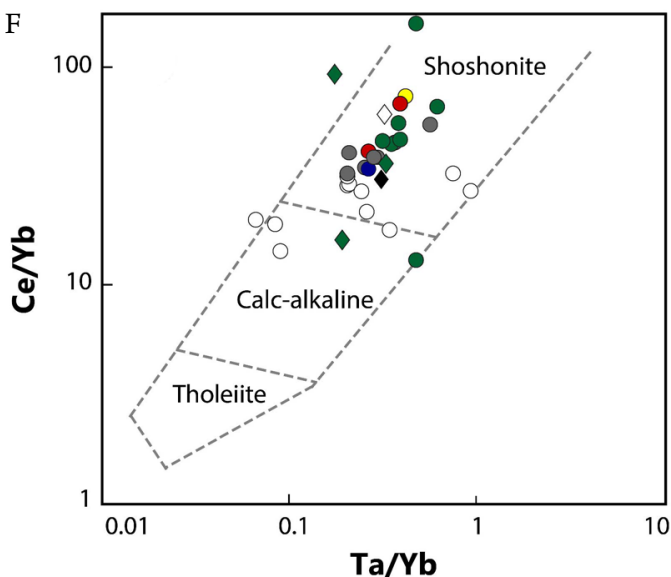

MME: microgranular mafic enclave; CHE: cumulate hornblendite enclave.

Figure 6. Geochemical diagrams applied to studied rocks. (A) Total alkali versus silica (Le Bas et al. 1986) with the demarcation of subalkaline and alkaline series according to Irvine and Baragar (1971). (B) AFM diagram (Irvine \& Baragar 1971) showing the fields of cumulate and non-cumulate mafic-ultramafic rocks related to arc environments (Beard 1986). (C) $\left(\mathrm{Na}_{2} \mathrm{O}+\mathrm{K}_{2} \mathrm{O}-\mathrm{CaO}\right)$ versus $\mathrm{SiO}_{2}$ and (D) $\mathrm{FeOt} /$ $\left(\mathrm{FeOt}+\mathrm{MgO}\right.$ ) versus $\mathrm{SiO}_{2}$ with Cordilleran granitoids area defined by Frost et al. (2001). (E) $\mathrm{Na}_{2} \mathrm{O}$ versus $\mathrm{K}_{2} \mathrm{O}$ (Turner et al. 1996). (F) Ta/ $\mathrm{Yb}$ versus $\mathrm{Ce} / \mathrm{Yb}$ (Pearce 1982). 
$\mathrm{Th}-\mathrm{Hf} / 3-\mathrm{Nb} / 16$ tectonomagmatic diagram (Wood 1980) for the gabbros and diorites exhibit composition similar to calc-alkaline basalts (Fig. 9A). On the other hand, the granitoid rocks plot in the field of volcanic arc granites (Pearce et al. 1984; Fig. 9B). In the $\mathrm{Zr} / \mathrm{TiO}_{2}$ versus $\mathrm{Ce} / \mathrm{P}_{2} \mathrm{O}_{5}$ tectonic discriminant diagram for potassic rocks (Müller et al. 1992), the analyzed samples are essentially located in the continental arc field (Fig. 9C).

A

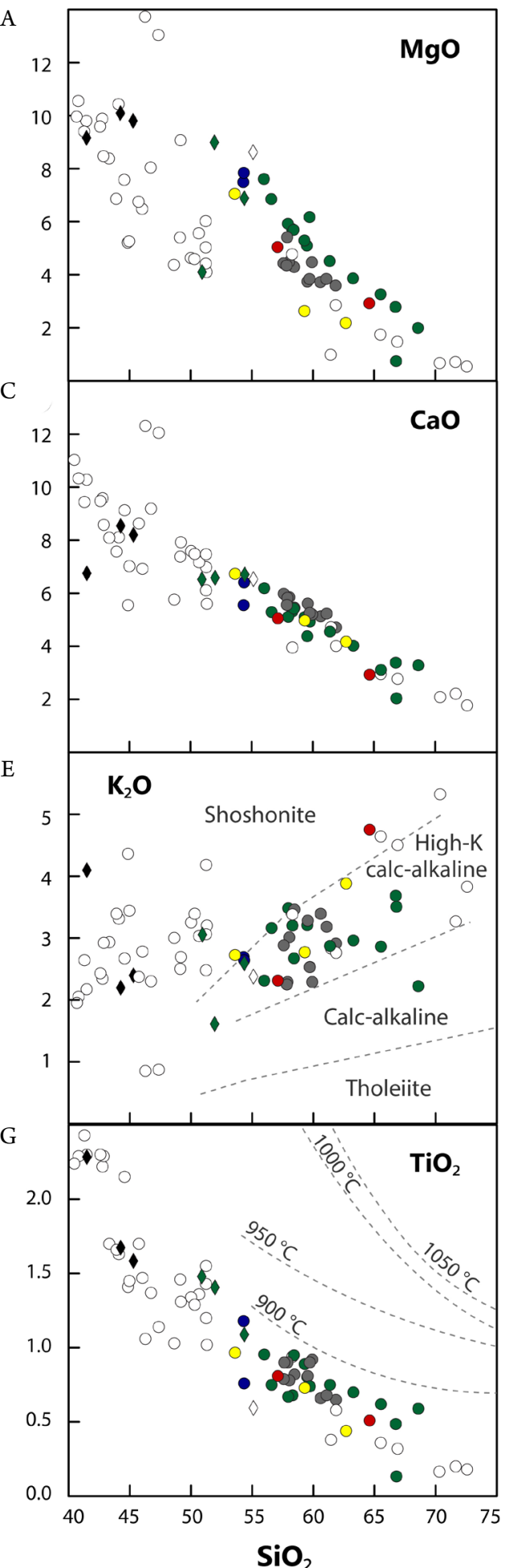

\section{DISCUSSION}

\section{Crystallization conditions}

The chemical composition of pyroxene, amphibole, and biotite from studied rocks the Macururé Mafic suite is characterized by high magnesium content (Pereira et al. 2017b, 2019), which is typical of crystallization under high oxygen fugacity (Anderson \& Smith 1995, Czamanske \& Wones 1973).

B

$\mathrm{D}$

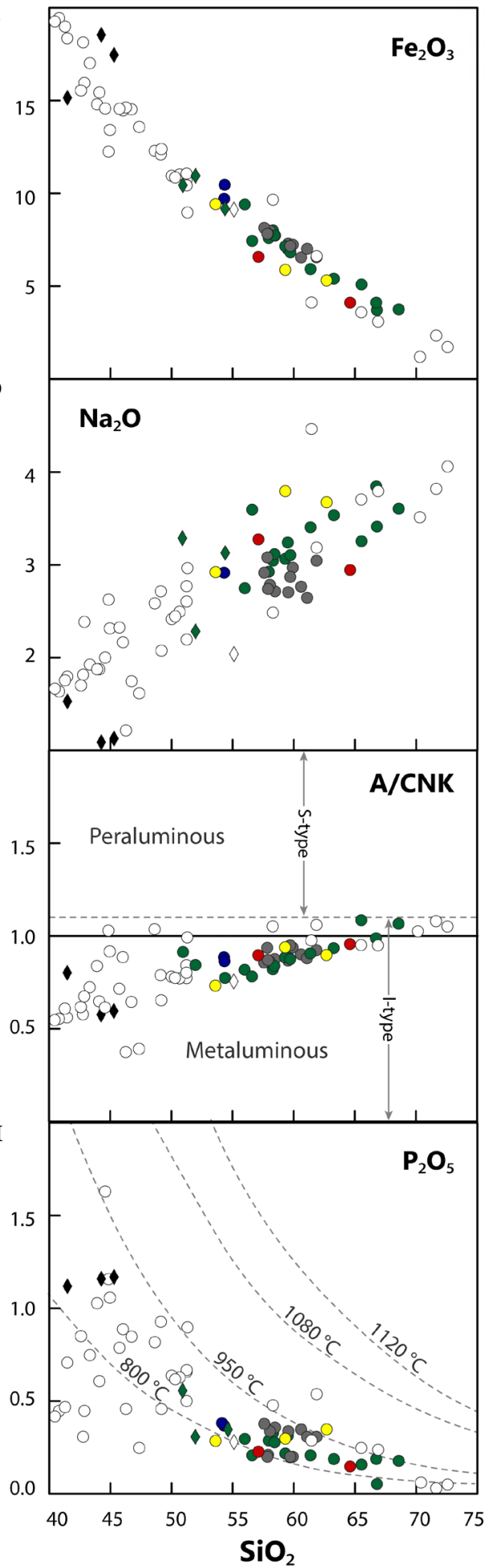

Figure 7. Bivariate diagrams using $\mathrm{SiO}_{2}$ as differentiation index. Fields of tholeiite, calc-alkaline, high-K calc-alkaline, and shoshonite series in (E) according to Peccerillo and Taylor (1976). (F) Alumina saturation index of Shand (1943) defined as the molar ratio $\mathrm{Al}_{2} \mathrm{O}_{3} /$ $\left(\mathrm{CaO}+\mathrm{Na}_{2} \mathrm{O}+\mathrm{K}_{2} \mathrm{O}\right)$ and limit between $\mathrm{S}$ - and I-type granites equal to 1.1 (Chappell \& White 2001). Isotherms in $(\mathrm{G})$ and $(\mathrm{H})$ are from respectively Green and Pearson (1986) and Green and Watson (1982). 
The presence of magmatic epidote in Capela, Pedra Branca, and Camará stocks is also compatible with oxidizing conditions, close to the NNO buffer (Pereira et al. 2019, Sial et al. 1999). Euhedral titanite with well-developed twinning was identified in rocks of Capela stock and certainly represent early minerals, which suggest that oxidizing conditions were reached since the initial stages of crystallization.

Garnet with a high-grossular and low-spessartine contents in assemblages with amphibole and calcic plagioclase, such as those reported in Capela and Dores' stocks by Pereira et al. (2019), indicate emplacement pressures greater than 8.0 kbar (Green 1992, Narduzzi et al. 2017). In addition, the presence of magmatic epidote in these rocks suggests medium- to high-pressure crystallization and rapid ascension rates (Zen \& Hammarstrom 1984, Sial et al. 1999). Calcic garnet and magmatic epidote are an unusual mineralogical assemblage which has been described in I-type metaluminous plutons crystallized at high-pressure in arc settings (Narduzzi et al. 2017).

Experiments under hydrous conditions performed by Green \& Pearson (1986) for mafic, intermediate, and acidic compositions show a significant correlation between $\mathrm{TiO}_{2}$ and $\mathrm{SiO}_{2}$ contents in magmas which coexist with Ti-rich accessory phases. When applying this relationship to the studied rocks,
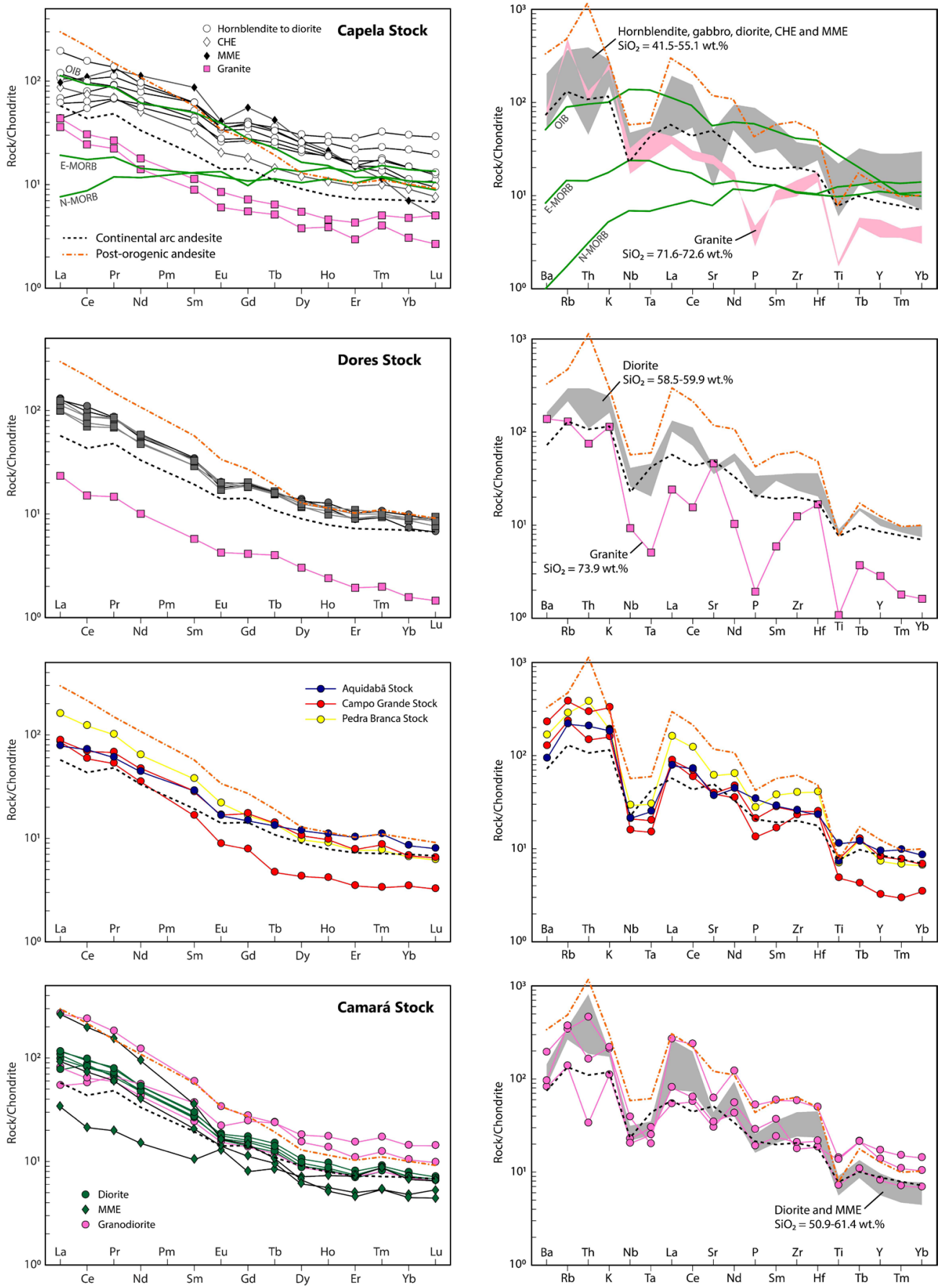

MME: microgranular mafic enclave; CHE: cumulate hornblendite enclave.

Figure 8. Chondrite-normalized REE (Nakamura 1974) and multielement (Thompson 1982) patterns. Trace elements composition of N-MORB, E-MORB, OIB (Sun \& McDonough 1989), continental arc andesite (Kelemen et al. 2007) and post-orogenic shoshonitic andesite (Pe-Piper et al. 2009) are displayed as comparison. Square symbols correspond to data from Santos (2014). 
the temperatures obtained are lower than $900^{\circ} \mathrm{C}$ (Fig. 7G), reflecting the typical low-titanium content of orogenic magmas.

Green and Watson (1982) demonstrated the dependence of apatite saturation on the $\mathrm{SiO}_{2}$ content of the magma, temperature and, in a smaller range, on pressure. Estimated temperatures following the apatite saturation method range from 800 to $950^{\circ} \mathrm{C}$ (Fig. $7 \mathrm{H}$ ). The scatter distribution for samples with $\mathrm{SiO}_{2}<50$ wt.\% may indicate disequilibrium crystallization or apatite accumulation.

\section{Microstructures and effects of metamorphism}

The rocks from Camará, Capela and Dores' stocks generally show a flat-lying foliation defined by the orientation of mafic minerals and feldspars (Figs. 3B and 3E). This foliation is crossed by high-angle foliation, which is recorded in Dores and Capela stocks. The alignment of primary minerals, besides quartz and biotite deformed in ductile regime, suggests that these rocks were emplaced synchronously to the tangential deformation event in the SOS. The orientation of microgranular enclaves and metasedimentary xenoliths relatively parallel to the host rock foliation supports this hypothesis.

Evidence of ductile deformation is also provided by feldspar, which exhibits undulose extinction, kink folds, and mechanical twinning. Quartz commonly presents well-marked undulose extinction and subgrains. In this situation, grain boundary migration indicated by irregular contacts, with interpenetrating saw-like morphology between the newly formed crystals. Comminution of quartz grains associated with recrystallization and elongate leads to the formation of ribbons. Locally, quartz crystals exhibit chessboard subgrains texture (Fig. 3C), typical of high-temperature deformation (Passchier \& Trouw 2005). Deformation of micas led to orientation, undulose extinction, and kink bands (Fig. 3K). The evidence of deformation is compatible with a metamorphic temperature higher than $450^{\circ} \mathrm{C}$ (Paterson et al. 1989, Passchier \& Trouw 2005), in amphibolite facies.
Textures that indicate static recrystallization are observed in quartz and feldspar, which locally exhibit polygonal texture. Sometimes, this recrystallization occurs in the pressure shadows of plagioclase porphyroclasts. In this situation, straight contacts and triple junctions predominate.

Transformations of the primary paragenesis are common. Crystals of epidote, carbonate, and sericite replace plagioclase. Biotite replaces amphibole along cleavages (Fig. 3I), sometimes producing pseudomorphs. The composition of amphibole also records late reequilibration, suggested by the composition of actinolite-tremolite (Pereira et al. 2019). Biotite is partially chloritized and has thin exsolved rutile needles, which are typically interpreted as a result of retrograde reactions involving titanium loss. Granular titanite occurs along cleavages or in the edges of altered biotite and amphibolite, indicating its secondary character (Paterson et al. 1989).

In summary, textural observations indicate that the studied stocks result from intrusive magmas during early- to syn-collisional stages, based on structures of ductile deformation compatible with the metamorphic amphibolite facies conditions. Therefore, the magmatic assemblage experienced secondary transformations, evidenced by minerals such as actinolite-tremolite, chlorite, biotite, sericite, epidote, and titanite.

\section{Crustal contamination}

Characterizing the source of mafic magmas is a difficult task for the susceptibility of these liquids to interact with the host rocks during the rising or the accommodation within the crust, modifying its elementary and isotopic composition.

The presence of older zircon cores in the Campo Grande sample suggests some contamination or source inheritance. In Macururé Group, there are no records of zircon grains younger than $900 \mathrm{Ma}$ (Oliveira et al. 2015b) and igneous rocks with crystallization age around $700 \mathrm{Ma}$ in the SOS are recognized only in Canindé Domain (Oliveira et al. 2010). Moreover, the older cores generally show prismatic forms, sometimes with bipyramidal endings, which is not expected
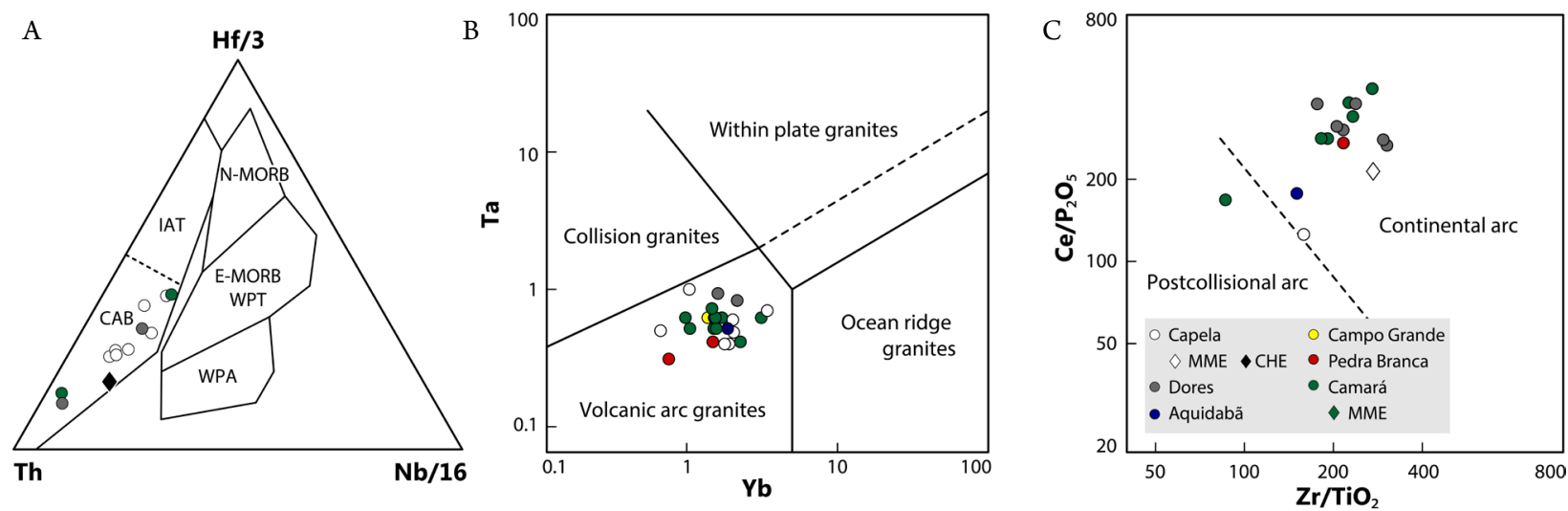

CAB: calc-alkaline basalt; IAT: island arc tholeiite; N-MORB: normal middle ocean ridge basalt; E-MORB: enriched middle ocean ridge basalt; WPT: within plate tholeiite; WPA: within plate alkali basalt; MME: microgranular mafic enclave; CHE: cumulate hornblendite enclave.

Figure 9. Tectonic environments discrimination diagrams. (A) $\mathrm{Th}-\mathrm{Hf} / 3-\mathrm{Nb} / 16$ (Wood 1980) for samples with $\mathrm{SiO}_{2}<52 \%$. (B) $\mathrm{Yb}$ versus $\mathrm{Ta}$ (Pearce et al. 1984) for silica-oversaturated samples. (C) $\mathrm{Zr} / \mathrm{TiO}_{2}$ versus $\mathrm{Ce} / \mathrm{P}_{2} \mathrm{O}_{5}$ for samples within the compositional ranges proposed by Müller et al. (1992). 
to grains that survive to the sedimentary cycle (Corfu et al. 2003). Hence, they are more likely to represent inheritances of the source area. Paleoproterozoic ages $(\sim 2,2 \mathrm{Ga})$ also were identified by Long et al. (2005) in Coronel João Sá batholith, which interpreted them as an inheritance of magma source.

Metapelitic xenoliths partially assimilated occur in Capela and Camará stocks, which could suggest some crustal participation. But these are punctual features that occur in a limited area, generally close to borders of these intrusions.

Moderate crustal contamination results in negative $\mathrm{Nb}-\mathrm{Ta}$ and positive $\mathrm{Zr}$-Hf anomalies, considering the greater abundance of the latter elements in crustal rocks (Rudnick \& Gao 2003). The absence of negative $\mathrm{Zr}$-Hf anomalies in the rocks of the studied stocks (Fig. 8) suggests that the interaction with adjacent rocks was not a significant factor for its composition. The $\mathrm{Nb}$ and $\mathrm{Ta}$ low-contents certainly reflect source heritage, since they are present in the most primitive terms, such as in hornblendites and gabbros of Capela stock (Fig. 8). Thus, Nb-Ta depletions are possibly related to an active or inherited subduction component (Pearce 1983).

The LREE contents are greater than those of continental crust (Rudnick \& Gao 2003), indicating that the crustal assimilation could not significantly affect the LREE composition of these rocks. Furthermore, the absolute concentration of some incompatible elements (e.g., $\mathrm{Ba}, \mathrm{Sr}, \mathrm{La}$ ) in the studied mafic rocks are higher than those observed in the continental crust, implying a strongly enriched source. Therefore, the enriched character of the hornblendites, gabbros, and diorites is more suitable with a heritage of the mantle source.

\section{Nature of the source}

High-K diorites enriched in LILE are recognized in many plutons of the Borborema Province and the authors attribute these characteristics to the incoming of Paleoproterozoic crustal material into the mantle during the Transamazonic tectonic cycle (Neves \& Mariano 1997, Mariano et al. 2001, Hollanda et al. 2003). Brito et al. (2009) propose that the rocks of the Serra do Catu batholith, which is intrusive in the interface between the SOS and PEAL terrains, were produced by the interaction between a fertile lithospheric mantle and the juvenile igneous rocks of the SOS. Silva Filho et al. (1997) suggested that the Brasiliano Orogeny did not add juvenile material to the continental crust of the SOS and the high LILE/HFSE ratios in granites from this domain is a subduction-related feature acquired from previous orogenic cycles. In Macururé Domain, Fontes et al. (2018) and Lisboa et al. (2019) evoke the melting of a previously metasomatized subcontinental lithospheric mantle to explain the genesis of potassic to ultrapotassic magmas from Glória Norte massif. Additionally, many other plutons in the SOS host mafic enclaves with shoshonitic and ultrapotassic affinities (Oliveira 2014, Silva 2014, Conceição et al. 2016), suggesting the existence of an enriched mantle source responsible for the origin of these rocks.

Gabbros and diorites are the most primitive terms of the studied intrusions and these rocks are $\mathrm{SiO}_{2}$-poor and $\mathrm{MgO}$ rich. Oliveira et al. (2015a) suggest that the magmas of Camará stock resulted from the mixture between a basaltic component from the lower and the upper crusts, being the last one possibly represented by the metasedimentary rocks of the Macururé Group. However, the compositions of the studied rocks point out derivation from a mantle source.

The high $\mathrm{CaO}$ and $\mathrm{Al}_{2} \mathrm{O}_{3}$ contents in the gabbros and diorites are distinct from those expected during the partial melting of a refractory peridotite mantle (harzburgitic or dunitic), suggesting that the magmas were produced by the melting of a fertile lherzolite source. These observations are compatible with the strong enrichment in LILE and LREE (such as K, $\mathrm{Rb}, \mathrm{Ba}$ ), and depletions in HFSE and HREE (such as $\mathrm{Ti}, \mathrm{Nb}$, $\mathrm{Ta}, \mathrm{Y})$. In addition, their relatively flat $\operatorname{HREE}\left(\mathrm{Dy}_{\mathrm{N}} / \mathrm{Yb}_{\mathrm{N}} \sim\right.$ 1.5) in chondrite-normalized patterns (Fig. 8) suggests a shallow melting, from mantle source in the spinel stability field.

The lithospheric mantle is HFSE-depleted and HREEenriched in relation to the asthenospheric mantle (Smith et al. 1999). Thus, low $\mathrm{Nb} / \mathrm{La}$ ratios are features of magmas derived from the lithospheric mantle, whereas higher $\mathrm{Nb}$ / La ratios indicate asthenospheric derivation, similar to the Ocean Island Basalt (OIB) magmas source. The low $\mathrm{Nb} / \mathrm{La}$ values in diorites and gabbros (Fig. 10A) are consistent with a lithospheric mantle derivation. In the $\mathrm{Nb} / \mathrm{Yb}$ versus $\mathrm{Th} /$ $\mathrm{Yb}$ diagram (Pearce 2008), the samples of all the stocks lie above the mantle enrichment trend line (MORB-OIB) and within the continental arc field (Fig. 10B). The vertical trend described for the rocks on this diagram reflects the addition of crustal components in the mantle, possibly during a subduction episode.

The compositional variability of the rocks in destructive plate limits has been attributed to the enrichment of the subcontinental lithospheric mantle by the income of hydrous fluids derived from the altered oceanic crust, volatile-rich melts or subducted sediments (Pearce 1983, Class \& Goldstein 1997, Elliott 2003). The input of crustal material in the mantle promotes the formation of exotic mineralogy and fertilization in incompatible elements. The studied mafic rocks show a decrease of the $\mathrm{Ba} / \mathrm{Nb}, \mathrm{K} / \mathrm{Nb}, \mathrm{Rb} / \mathrm{Nb}, \mathrm{Cs} / \mathrm{Nb}$, and $\mathrm{Rb} / \mathrm{Sr}$ ratios with the increase of $\mathrm{Nb}$. This behavior is common in alkali basalts and has been explained to the control of K-rich residual phases in the mantle (Sun \& McDonough 1989). Pargasite and phlogopite are the main host minerals of $\mathrm{K}, \mathrm{Rb}$, and $\mathrm{Ba}$ in the mantle. $\mathrm{Ba}$ and $\mathrm{Rb}$ behave like compatible elements in respect to phlogopite, while $\mathrm{Rb}$ is moderately compatible with amphibole (Class \& Goldstein 1997). Thus, magmas produced in equilibrium with residual phlogopite are expected to have elevated $\mathrm{Rb} / \mathrm{Sr}$ and lower $\mathrm{Ba} / \mathrm{Rb}$ ratios than those generated from amphibole-rich sources. The $\mathrm{Ba} / \mathrm{Rb}(5.61-22.02)$ and $\mathrm{Rb} / \mathrm{Sr}$ (0.11-0.45) ratios in the studied rocks (Fig. 10C) suggest that the diorites and gabbros were generated by partial melting of a phlogopite-bearing mantle source (Furman \& Graham 1999).

During subduction events, LILE and LREE are transported by fluids derived from the altered oceanic crust, while marine sediments are more enriched in HREE and HFSE (Hawkesworth et al. 1997, Plank 2014). The mafic rocks have $\mathrm{Th} / \mathrm{Yb}$ and $\mathrm{Sr} /$ $\mathrm{Nb}$ ratios suitable with melts produced from sub-arc peridotites that experienced enrichment by interaction with subducted sediments (Fig. 10D) (Woodhead et al. 1998). In synthesis, 
geochemical data suggest that the parental magmas of the studied diorites and gabbros could have been generated by partial melting of an enriched lithospheric mantle in the spinel stability field, whose metasomatism occurred through the interaction with subducted sediments.

\section{Petrogenesis}

The rocks of the studied intrusions were emplaced contemporaneously (ca. $630 \mathrm{Ma}$ ) and show strong correlations between major and trace elements, suggesting genetic relations between them. The observed compositional variation could result from variable degrees of partial melting, fractional crystallization, magma mixing or contamination with host rocks.

\section{Ultrabasic, basic and intermediate rocks}

The $\mathrm{MgO}$ contents ( $\sim 6 \mathrm{wt} . \%)$, the concentration of transition metals, and the presence of hornblendite cumulates argue that gabbros and diorites do not represent primary basaltic/andesitic magmas, but liquids that experienced some fractionation. In Capela stock, the highest average values of $\mathrm{Cr}$ and $\mathrm{V}$ occur in the hornblendites $(\mathrm{Cr}=160-590 \mathrm{ppm}$; $\mathrm{V}=373-551 \mathrm{ppm})$ and decrease toward the gabbros and diorites $(\mathrm{Cr}=60-610 \mathrm{ppm} ; \mathrm{V}=89-286 \mathrm{ppm})$, suggesting that the cumulates extraction was responsible for the depletion of these compatible elements in remaining magmas. Pereira et al. (2019) describe normal zoning in crystals of plagioclase, amphibole, and garnet from Capela stock, reinforcing the importance of the fractional crystallization in its magmatic evolution.

In an individual intrusion, $\mathrm{Na}_{2} \mathrm{O}$ increases while $\mathrm{MgO}$, $\mathrm{Fe}_{2} \mathrm{O}_{3}, \mathrm{CaO}, \mathrm{TiO}_{2}$, and $\mathrm{P}_{2} \mathrm{O}_{5}$ decrease with the increase of $\mathrm{SiO}_{2}$ (Fig. 8). The negative correlation of $\mathrm{MgO}, \mathrm{Fe}_{2} \mathrm{O}_{3}$, and $\mathrm{CaO}$ with $\mathrm{SiO}_{2}$ reflects the fractionation of mafic minerals, such as enstatite, diopside, hornblende, biotite, and garnet. $\mathrm{P}_{2} \mathrm{O}_{5}$ and $\mathrm{TiO}_{2}$ decreasing with increasing of $\mathrm{SiO}_{2}$ imply fractionation of Ti-bearing phases and apatite. Plagioclase fractionation is evidenced by $\mathrm{CaO}$ decrease toward more evolved samples, besides negative $\mathrm{Sr}$ and $\mathrm{Eu}$ anomalies (Fig. 8). The tendencies ascending of $\mathrm{Na}_{2} \mathrm{O}$ and scatter of $\mathrm{K}_{2} \mathrm{O}$, suggest that potassic feldspar was a late crystallizing phase. Furthermore, REE abundances decrease systematically from hornblendites to gabbros and diorites, which is consistent with fractional crystallization of mantle-derived basaltic magma, associated with the removal of REE-rich phases such as titanite, allanite, apatite, and zircon. These are ubiquitous accessory minerals in the studied rocks.
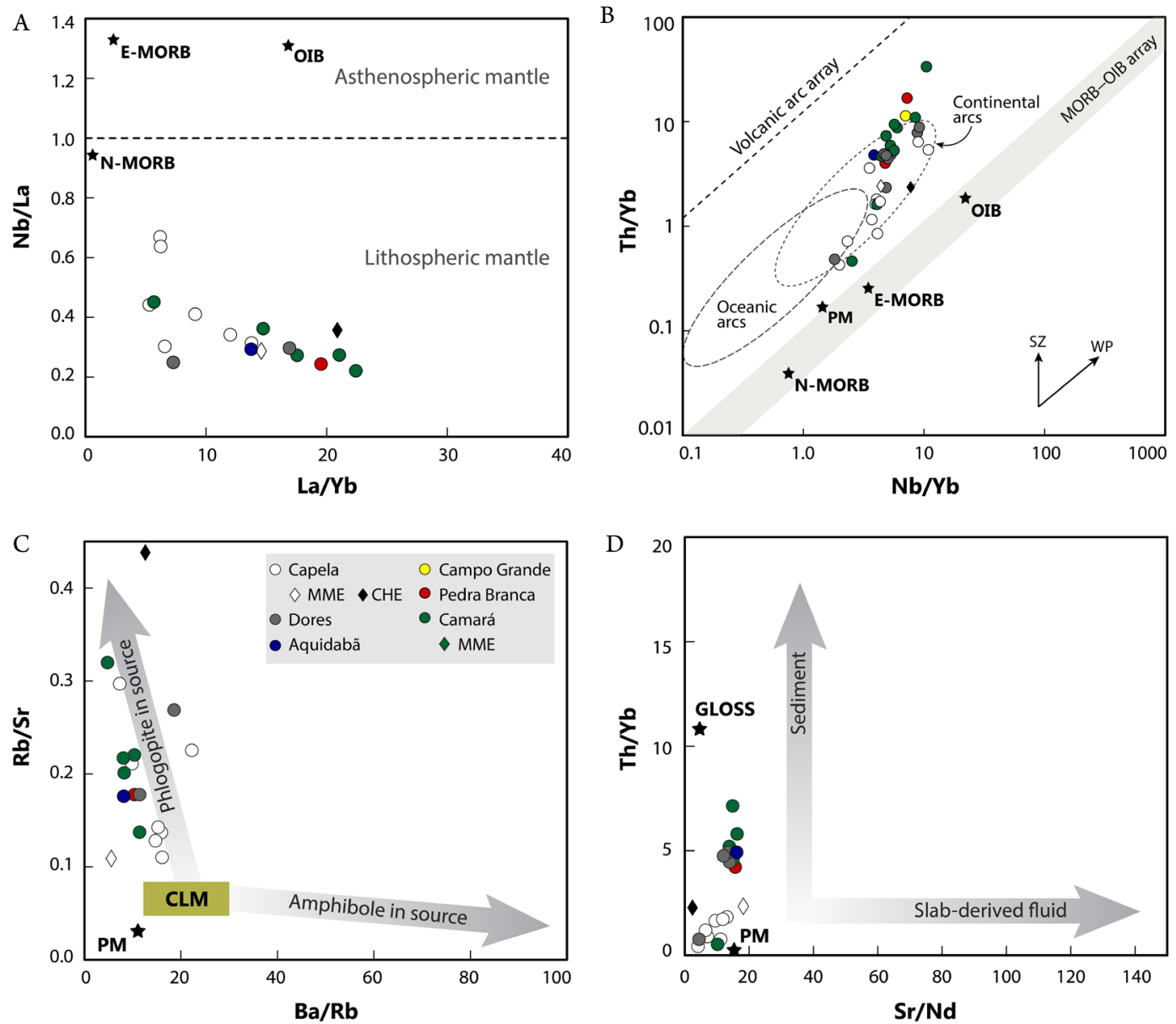

Figure 10. Nature of the source. (A) La/Yb versus $\mathrm{Nb} / \mathrm{La}$ (Smith et al. 1999). (B) $\mathrm{Nb} / \mathrm{Yb}$ versus $\mathrm{Th} / \mathrm{Yb}$ (Pearce 2008) showing within-plate (WP) and subduction zone (SZ) enrichment vectors. Fields of continental and oceanic arcs are from Pearce (2014). (C) Ba/Rb versus $\mathrm{Rb} /$ Sr (Furman \& Graham 1999) with an area of the common lithospheric mantle (CLM). (D) Sr/Nd versus Th/Yb (Woodhead et al. 1998) with enrichment tendencies related to sediments and fluids. Values of N-MORB, E-MORB, OIB and primitive mantle (PM) according to Sun and McDonough (1989). Global subducting sediment (GLOSS) composition from Plank (2014). In (A), (C) and (D) were used only the samples with $\mathrm{MgO}>5$ wt.\%. 
According to Cocherie (1986), elements with distinct global partition coefficients plotted in logarithmic diagrams allow the identification of the main petrogenetic processes involved in the genesis of igneous rocks. The high-slope negative trend shown in the $\mathrm{Sr}$ versus Sm diagram (Fig. 11A) suggests that the observed compositions were controlled by fractional crystallization. Figure 11 illustrates the strong control exercised by the fractional crystallization of amphibole, plagioclase, and biotite in the chemical evolution of the studied rocks. The genesis of hornblendites can be explained by the crystallization and accumulation of amphibole from a trachytic basaltic magma. Therefore, variable degrees of fractional crystallization of apatite, Fe-Ti oxides, pyroxene, amphibole, biotite, and plagioclase would be the main process for causing the compositional variations in the different intrusions.

\section{Acidic rocks}

The felsic granitoids represent a small percentage of the outcropping rocks. The multi-elemental diagram shows very distinct spectra form granitoids and mafic rocks, which occur associated with them, indicating that they were not derived from the same source. Additionally, REE patterns of gabbro and diorites are characterized by more significant negative europium anomalies than those observed in granites, suggesting that the acidic granitoids did not evolve by fractional crystallization of the same primary magma.

The liquidus temperature of basaltic magmas mantle-derived $\left(\sim 1,200^{\circ} \mathrm{C}\right)$ is higher than the fusion point of most minerals in crustal rocks, implying that the melting of host rocks is inevitable (Watson 1982). Bergantz (1989) demonstrated that the emplacement of underplating basaltic magmas in metapelites may produce great volumes of felsic magmas, while granite and tonalite protoliths do not provide substantial amounts of magma. Relatively high $\mathrm{SiO}_{2}$ and $\mathrm{K}_{2} \mathrm{O}$ values, allied to the presence of aluminous minerals (biotite \pm muscovite), suggest the participation of metasedimentary rocks (e.g., the mica schists of the Macururé Group) in the genesis of these granites. However, a purely pelitic source would produce rocks strongly peraluminous and depleted in $\mathrm{MgO}, \mathrm{FeO}$, and $\mathrm{TiO}_{2}$ (Patiño Douce \& Harris 1998), a condition which is not verified. Also, the melting of amphibolites usually results in peraluminous liquids, due to their low alkalis total (Beard \& Lofgren 1991, Patiño Douce \& Beard 1995).

The $\mathrm{Na}_{2} \mathrm{O}$ and $\mathrm{K}_{2} \mathrm{O}$ contents in acidic granitoids samples are similar to those reported for melts of mediumto high- $\mathrm{K}$ basaltic rocks. In the $\mathrm{Al}_{2} \mathrm{O}_{3} /(\mathrm{FeOt}+\mathrm{MgO})$ - $3 \mathrm{CaO}-5\left(\mathrm{~K}_{2} \mathrm{O} / \mathrm{Na}_{2} \mathrm{O}\right)$ ternary diagram proposed by Laurent et al. (2014), the acidic rocks from Capela stock lie within the field of high-K mafic melts (Fig. 12). Experimental data reveal that high-K calc-alkaline I-type granites are generated by partial melting of K-rich mafic to intermediate metaigneous rocks (Roberts \& Clemens 1993). Therefore, the likely source of these granites could be a lower basaltic crust enriched in incompatible elements, whose anatexis may have been triggered by
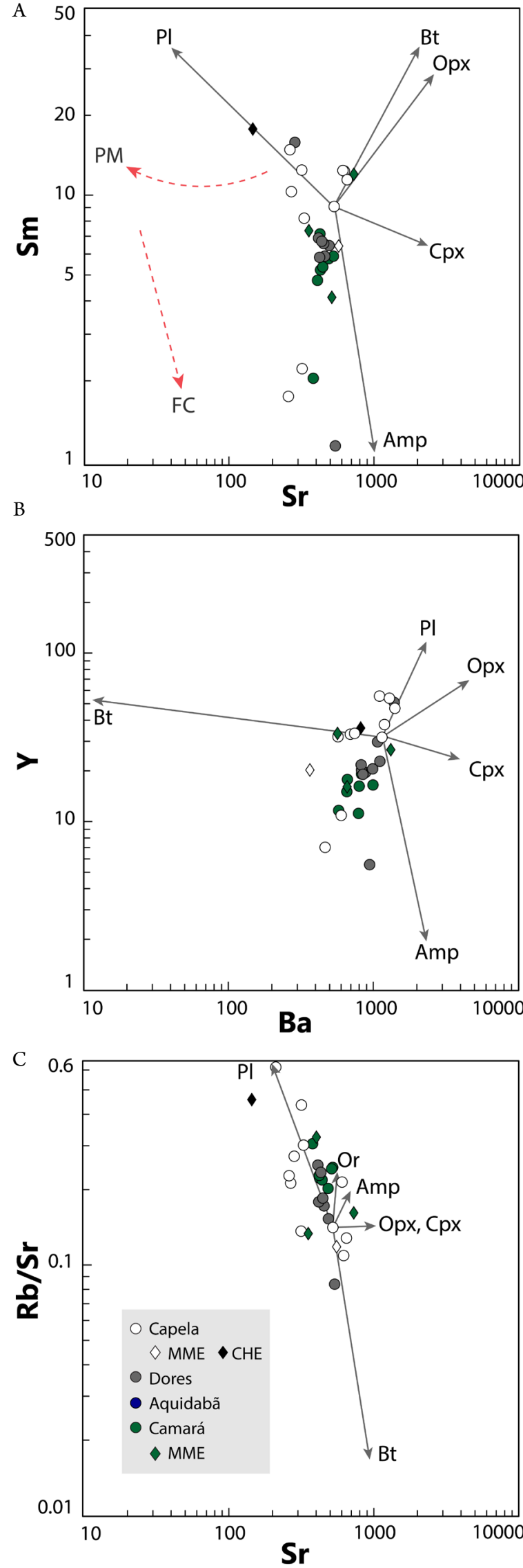

MME: microgranular mafic enclave; CHE: cumulate hornblendite enclave. Figure 11. Fractional crystallization trends of amphibole (Amp), biotite $(\mathrm{Bt})$, clinopyroxene $(\mathrm{Cpx})$, orthopyroxene (Opx), orthoclase (Or), and plagioclase (Pl). Partition coefficients were compiled from Rollinson (1993). Evolutive tendencies by fractional crystallization (FC) and partial melting (PM) correspond to red dashed arrows in (A). 
the emplacement of mantle-derived magmas during the Brasiliano Orogeny in the SOS.

\section{Regional implications}

The Macururé Mafic Suite comprises bodies of little volume expression, which were intruded about $630 \mathrm{Ma}$. These rocks exhibit D2 event deformation, characterized by a low angle foliation marked by the orientation of mafic minerals, plagioclase, and quartz. These characteristics are similar to those reported by Bueno et al. (2009) for the pre- to syn-collisional plutons in the Macururé Domain.

According to Basei et al. (2010), the crustal evolution of Borborema Province at about $770 \mathrm{Ma}$ was marked by the opening of oceanic and proto-oceanic basins of different nature, some of them which are recognized in the Ceará Central (Arthaud et al. 2015), Riacho do Pontal (Caxito et al. 2016), and Sergipano (Oliveira et al. 2010) domains. These authors attribute this episode to the break-up of the Rodinia continent, before the beginning Brasiliano Orogeny. Ages of ca. 780 Ma have been registered in zircon crystal core of the Campo Grande stock, possibly registering the influence of sources related to this event.

The Macururé Mafic Suite show petrographic and geochemical characteristics of Amphibole-rich Calc-alkaline Granitoids (ACG) association, which according to Barbarin (1999) constitute vast elongated batholiths parallel to the trenches in active continental margins. They are mostly magnesian, feature largely related to a subduction environment (Frost et al. 2001). The K-rich character of the studied rocks, even in the most primitive terms, is a remarkable feature. The igneous rocks of the SOS are essentially high-K calc-alkaline to shoshonitic, with ultrapotassic terms subordinate (Silva Filho et al. 1997, Oliveira et al. 2015a, Conceição et al. 2016, Fontes et al. 2018, Lisboa et al. 2019, Santos et al. 2019). The potassic magmatism is typically associated to post-collisional stages, but also

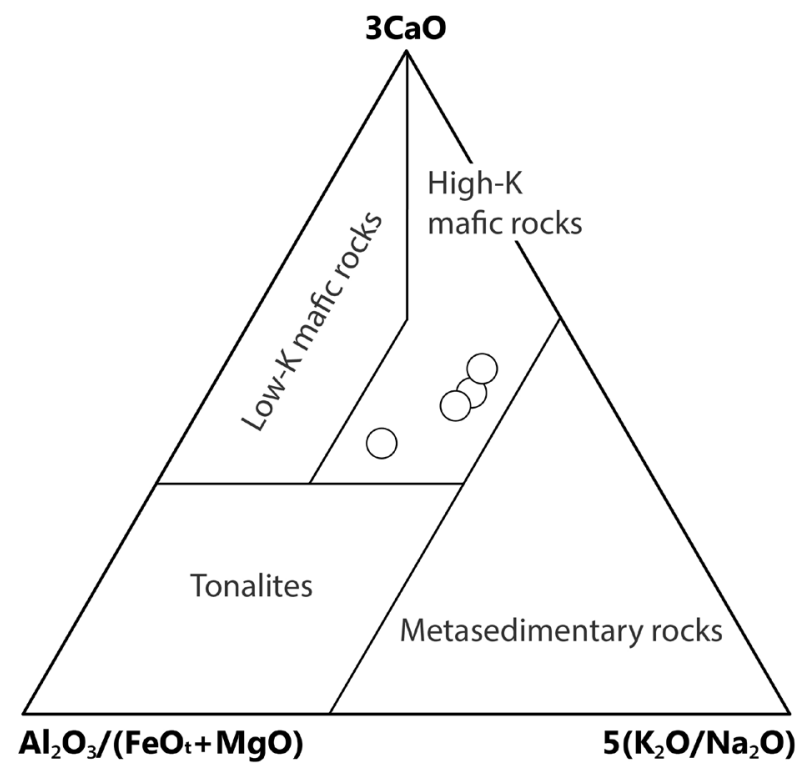

Figure 12. Granite compositions from Capela stock plotted in the $\mathrm{Al}_{2} \mathrm{O}_{3} / \mathrm{FeOt}+\mathrm{MgO}-3 \mathrm{CaO}-5 \mathrm{~K}_{2} \mathrm{O} / \mathrm{Na}_{2} \mathrm{O}$ diagram (Laurent et al. 2014). The fields represent the composition of melts derived from tonalites, metasediments, low- and high-K mafic protoliths. occurs widely in active continental margins (Wilson 1989, Müller et al. 1992, Barbarin 1999), presenting genetic relation with the subduction zones.

For the Southern Borborema Province, Oliveira et al. (2015a) proposed that the oldest granitoids from SOS are related to the build-up of a continental arc from 630 to $617 \mathrm{Ma}$, resulting from the convergence of the PEAL Domain and the São Francisco paleoplate. According to this evolutive model, the subduction of the São Francisco oceanic lithosphere was followed by slab breakoff, allowing the rising of the asthenosphere and the generation of magmas with shoshonitic affinity. This suggests that the generation of Macururé Mafic Suite would be related to the breakoff of the subducting ocean plate.

In the PEAL Domain, the span 650-620 Ma is characterized by the emplacement of high-K calc-alkaline to shoshonite plutons, with characteristics of arc magmatism (Silva Filho et al. 2016, Silva et al.2016). In the Riacho do Pontal belt, the period between 630 and 620 Ma was marked by subduction, inversion of basins, obduction of oceanic crust, and synorogenic sedimentation (Caxito et al. 2016). In the African counterpart, this same interval is interpreted as a convergence stage, with high-grade metamorphism, associated with the emplacement of calc-alkaline plutons with ages ranging from 640 to $610 \mathrm{Ma}$ (Toteu et al. $2001,2004)$. These records suggest that the collisional event was broadly coeval in adjoining belts to the SOS.

\section{Conclusions}

The Capela (631 $\pm 3 \mathrm{Ma})$, Dores, Aquidabã (636 $\pm 4 \mathrm{Ma})$, Campo Grande (629 $\pm 9 \mathrm{Ma})$, Camará, and Pedra Branca stocks form Macururé Mafic Suite and were contemporaneously placed at $630 \mathrm{Ma}$. The intrusions are constituted of gabbros, diorites, monzonites, and granites, which exhibit evidence of ductile deformation compatible with amphibolite facies metamorphism. These rocks are high-K calc-alkaline to shoshonite, magnesian and present character of magmatism related to continental arc, as other SOS and PEAL intrusions. Chemical data suggest that gabbros and diorites were produced by partial melting of a sublithospheric fertile mantle and evolved by fractional crystallization in oxidizing conditions. The granites are not cogenetic and were possibly generated by melting of lower basaltic crust enriched in incompatible elements during the emplacement episode of the mafic magmas to which they are associated.

\section{ACKNOWLEDGMENTS}

This study was partly financed by the Coordenação de Aperfeiçoamento de Pessoal de Nível Superior Brazil (CAPES) Finance Code 001. The authors are grateful to the funding of projects 019.203.02538/2009-7 (PRONEX/FAPITEC/CNPq), 311008/2017-8 (CNPq-PQ), 310391/2017-2 (CNPq-PQ), 311008/2017-8 (CNPq-Universal 2016), and 403797/2016-0 (CNPq-Universal 2016). We also thank CPRM of Salvador (SUREG-SA) for all the support to sample preparation. We are grateful to the anonymous reviewers for comments and suggestions that have considerably improved the original manuscript. 


\section{ARTICLE INFORMATION}

Manuscript ID: 20190105. Received on: 10/09/2019. Approved on: 02/07/2020.

F.S.P. carried out the geological mapping and sampling, wrote the manuscript and prepared all figures and tables. M.L.S.R. performed the geochemical and geochronological analyses, revised the manuscript and contributed with petrological interpretations. H.C. contributed with the field works, petrographic descriptions and improved the manuscript with revisions and suggestions. A.L.B. helped with geological mapping and sampling.

Competing interests: The authors declare no competing interests.

\section{REFERENCES}

Aldanmaz E., Pearce J.A., Thirlwall M.F., Mitchell J.G. 2000. Petrogenetic evolution of late Cenozoic, post-collision volcanism in western Anatolia, Turkey. Journal of Volcanology and Geothermal Research, 102(1-2):67-95. https://doi.org/10.1016/S0377-0273(00)00182-7

Anderson J.L., Smith D.C. 1995. The effects of temperature and $\mathrm{fO}_{2}$ on the Al-in-hornblende barometer. American Mineralogist, 80(5-6):549-559. https://doi.org/10.2138/am-1995-5-614

Arthaud M.H., Fuck R.A., Dantas E.L., Santos T.J.S., Caby R., Armstrong R. 2015. The Neoproterozoic Ceará Group, Ceará Central domain, NE Brazil: Depositional age and provenance of detrital material. New insights from $\mathrm{U}_{-}$ $\mathrm{Pb}$ and $\mathrm{Sm}-\mathrm{Nd}$ geochronology. Journal of South American Earth Sciences, 58:223-237. https://doi.org/10.1016/J.JSAMES.2014.09.007

Barbarin B. 1999. A review of the relationships between granitoid types, their origins and their geodynamic environments. Lithos, 46(3):605-626. https://doi.org/10.1016/S0024-4937(98)00085-1

Basei M.A.S., Brito Neves B.B., Siga Junior O., Babinski M., Pimentel M.M., Tassinari C.C.G., Hollanda M.H.B., Nutman A., Cordani U.G. 2010. Contribution of SHRIMP U-Pb zircon geochronology to unravelling the evolution of Brazilian Neoproterozoic fold belts. Precambrian Research, 183(1):112-144. https://doi.org/10.1016/J.PRECAMRES.2010.07.015

Beard J.S. 1986. Characteristic mineralogy of arc-related cumulate gabbros: Implications for the tectonic setting of gabbroic plutons and for andesite genesis. Geology, 14(10):848-851. https://doi. org/10.1130/0091-7613(1986)14<848:CMOACG>2.0.CO;2

Beard J.S., Lofgren G.E. 1991. Dehydration melting and water-saturated melting of basaltic and andesitic greenstones and amphibolites at 1, 3, and 6.9 kb. Journal of Petrology, 32(2):365-401. https://doi.org/10.1093/ petrology/32.2.365

Bergantz G.W. 1989. Underplating and partial melting: implications for melt generation and extraction. Science, 245(4922):1093-5. https://doi. org/10.1126/science.245.4922.1093

Black L.P., Kamo S.L., Allen C.M., Davis D.W., Aleinikoff J.N., Valley J.W., Mundil R., Campbell I.H., Korsch R.J., Williams I.S., Foudoulis C. 2004. Improved ${ }^{206} \mathrm{~Pb} /{ }^{238} \mathrm{U}$ microprobe geochronology by the monitoring of a trace-element-related matrix effect; SHRIMP, ID-TIMS, ELA-ICPMS and oxygen isotope documentation for a series of zircon standards. Chemical Geology, 205(1-2):115-140. https://doi.org/10.1016/J. CHEMGEO.2004.01.003

Brito M.E.L., Silva Filho A.F., Guimarães I.P. 2009. Caracterização geoquímica e isotópica do batólito Serra do Catu e sua evolução da interface dos domínios Sergipano e Pernambuco-Alagoas, Província Borborema. Revista Brasileira de Geociências, 39(2):324-337.

Brito Neves B.B., Santos E.J., Van Schmus W.R. 2000. Tectonic history of the Borborema Province. In: Cordani U.G., Milani E.J., Thomaz Filho A., Campos D.A. (eds.), Tectonic evolution of South America. Rio de Janeiro, Fólio, p. 151-182.

Bueno J.F., Oliveira E.P., McNaughton N.J., Laux J.H. 2009. U-Pb dating of granites in the Neoproterozoic Sergipano Belt, NE-Brazil: implications for the timing and duration of continental collision and extrusion tectonics in the Borborema Province. Gondwana Research, 15(1):86-97. https://doi. org/10.1016/J.GR.2008.06.003

Caxito F.A., Uhlein A., Dantas E.L., Stevenson R., Salgado S.S., Dussin I.A., Sial A.N. 2016. A complete Wilson Cycle recorded within the Riacho do Pontal Orogen, NE Brazil: implications for the Neoproterozoic evolution of the Borborema Province at the heart of West Gondwana.
Precambrian Research, 282:97-120. https://doi.org/10.1016/J PRECAMRES.2016.07.001

Chappell B.W., White A.J.R. 2001. Two contrasting granite types: 25 years later. Australian Journal of Earth Sciences, 48(4):489-499. https://doi. org/10.1046/j.1440-0952.2001.00882.x

Class C., Goldstein S.L. 1997. Plume-lithosphere interactions in the ocean basins: constraints from the source mineralogy. Earth and Planetary Science Letters, 150(3-4):245-260. https://doi.org/10.1016/ S0012-821X(97)00089-7

Cocherie A. 1986. Systematic use of trace element distribution patterns in log-log diagrams for plutonic suites. Geochimica et Cosmochimica Acta, 50(11):2517-2522. https://doi.org/10.1016/0016-7037(86)90034-7

Conceição H., Rosa M.L.S., Conceição J.A., Lisboa V.A.C., Pereira F.S., Teles D.S., Fernandes D.M., Sousa E.S., Cruz J.W.S., Rezende H.J.C., Oliveira I.R., Souza J.M.D., Oliveira I.L. 2017. Magmatismos no Domínio Macururé, Sistema Orogênico Sergipano: estado do conhecimento. In: Simpósio de Geologia do Nordeste, 27., João Pessoa. Anais...

Conceição J.A., Rosa M.L.S., Conceição H. 2016. Sienogranitos leucocráticos do Domínio Macururé, Sistema Orogênico Sergipano, Nordeste do Brasil: Stock Glória Sul. Brazilian Journal of Geology, 46(1):6377. https://doi.org/10.1590/2317-4889201620150044

Corfu F., Hanchar J.M., Hoskin P.W.O., Kinny P. 2003. Atlas of zircon textures. Reviews in Mineralogy and Geochemistry, 53(1):469-500. https:// doi.org/10.2113/0530469

Czamanske G.K., Wones D.R. 1973. Oxidation during magmatic differentiation, Finnmarka Complex, Oslo Area, Norway: part 2, the mafic silicates. Journal of Petrology, 14(3):349-380. https://doi.org/10.1093/ petrology/14.3.349

Davison I., Santos R.A. 1989. Tectonic evolution of the Sergipano Fold Belt, NE Brazil, during the Brasiliano Orogeny. Precambrian Research, 45 (4):319342. https://doi.org/10.1016/0301-9268(89)90068-5

D'el-Rey Silva L.J.H. 1999. Basin infilling in the southern-central part of the Sergipano Belt (NE Brazil) and implications for the evolution of PanAfrican/Brasiliano cratons and Neoproterozoic sedimentary cover. Journal of South American Earth Sciences, 12(5):453-470. https://doi.org/10.1016/ S0895-9811(99)00034-6

Elliott T. 2003. Tracers of the slab. In: Eiler J. (ed.), Inside the Subduction Factory (Geophysical Monograph 138). Washington, American Geophysical Union, p. 23-45.

Fontes M.P., Conceição H., Rosa M.L.S., Lisboa V.A.C. 2018. Minettes do Stock Monzonítico Glória Norte: evidência de magmatismo ultrapotássico pós-orogênico, com assinatura de subducção, no Sistema Orogênico Sergipano. Geologia USP. Série Cientifica, 18(1):51-66. https://doi. org/10.11606/issn.2316-9095.v18-133599

Frost B.R., Barnes C.G., Collins W.J., Arculus R.J., Ellis D.J., Frost C.D. 2001. A geochemical classification for granitic rocks. Journal of Petrology, 42(11):2033-2048. https://doi.org/10.1093/petrology/42.11.2033

Furman T., Graham D. 1999. Erosion of lithospheric mantle beneath the East African Rift system: geochemical evidence from the Kivu volcanic province. Lithos, 48(1-4):237-262. https://doi.org/10.1016/ S0024-4937(99)00031-6

Green T.H. 1992. Experimental phase equilibrium studies of garnet-bearing I-type volcanics and high-level intrusives from Northland, New Zealand. Earth and Environmental Science Transactions of the Royal Society of Edinburgh, 83(1-2):429-438. https://doi.org/10.1017/S0263593300008105 
Green T.H., Pearson N.J. 1986. Ti-rich accessory phase saturation in hydrous mafic-felsic compositions at high P, T. Chemical Geology, 54(3-4):185-201. https://doi.org/10.1016/0009-2541(86)90136-1

Green T.H., Watson E.B. 1982. Crystallization of apatite in natural magmas under high pressure, hydrous conditions, with particular reference to "orogenic" rock series. Contributions to Mineralogy and Petrology, 79(1):96105. https://doi.org/10.1007/BF00376966

Guimarães I.P., Silva Filho A.F., Almeida C.N., Macambira M.B., Armstrong R. 2011. U-Pb SHRIMP data constraints on calc-alkaline granitoids with 1.3-1.6 Ga Nd TDM model ages from the central domain of the Borborema province, NE Brazil. Journal of South American Earth Sciences, 31(4):383396. https://doi.org/10.1016/J.JSAMES.2011.03.001

Hawkesworth C.J., Turner S.P., McDermott F., Peate D.W., van Calsteren P. 1997. U-Th isotopes in arc magmas: implications for element transfer from the subducted crust. Science, 276(5312):551-555. https://doi. org/10.1126/science.276.5312.551

Hollanda M.H.B.M., Pimentel M.M., Jardim de Sá E.F. 2003. Paleoproterozoic subduction-related metasomatic signatures in the lithospheric mantle beneath NE Brazil: inferences from trace element and $\mathrm{Sr}-\mathrm{Nd}-\mathrm{Pb}$ isotopic compositions of Neoproterozoic high-K igneous rocks. Journal of South American Earth Sciences, 15(8):885-900. https://doi. org/10.1016/S0895-9811(03)00014-2

Humphrey L., Allard G.O. 1969. Geologia da área do Domo de Itabaiana (Sergipe) e sua relação com a geologia do Geossinclinal de Propriá: um elemento tectônico recém-reconhecido no escudo brasileiro. Rio de Janeiro, PETROBRAS/CENPES, $160 \mathrm{p}$.

Irvine T.N., Baragar W.R.A. 1971. A Guide to the chemical classification of the common volcanic rocks. Canadian Journal of Earth Sciences, 8(5):523548. https://doi.org/10.1139/e71-055

Janoušek V., Farrow C.M., Erban V. 2006. Interpretation of whole-rock geochemical data in igneous geochemistry: introducing Geochemical Data Toolkit (GCDkit). Journal of Petrology, 47(6):1255-1259. https://doi. org/10.1093/petrology/egl013

Kelemen P.B., Hanghøj K., Greene A.R. 2007. One view of the geochemistry of subduction-related magmatic arcs, with an emphasis on primitive andesite and lower crust. Treatise on Geochemistry, 3:1-70. https://doi.org/10.1016/ B0-08-043751-6/03035-8

Laurent O., Martin H., Moyen J.F., Doucelance R. 2014. The diversity and evolution of late-Archean granitoids: evidence for the onset of "modernstyle" plate tectonics between 3.0 and 2.5 Ga. Lithos, 205:208-235. https:// doi.org/10.1016/J.LITHOS.2014.06.012

Le Bas M.J., Maitre R.W.L., Streckeisen A., Zanettin B. 1986. A chemical classification of volcanic rocks based on the total alkali-silica diagram. Journal of Petrology, 27(3):745-750. https://doi.org/10.1093/petrology/27.3.745

Lima M.M.C., Silva T.R., Ferreira V.P., Silva F.M.R. 2014. Metasedimentary rocks of the northern portion of the Macururé Domain, Sergipano Belt, Northeastern Brazil: geochemical characterization of their protoliths and tectonic implications. Estudos Geológicos, 24(2):89-107. https://doi. org/10.18190/1980-8208/estudosgeologicos.v24n2p89-107

Lisboa V.A.C., Conceição H., Rosa M.L.S., Fernandes D.M. 2019. The onset of post-collisional magmatism in the Macururé Domain, Sergipano Orogenic System: The Glória Norte Stock. Journal of South American Earth Sciences, 89:173-188. https://doi.org/10.1016/J.JSAMES.2018.11.005

Long L.E., Castellana C.H., Sial A.N. 2005. Age, origin and cooling history of the Coronel João Sá Pluton, Bahia, Brazil. Journal of Petrology, 46(2):255273. http://dx.doi.org/10.1093/petrology/egh070

Ludwig K. 2009a. SQUID 2: A User's Manual. Berkeley, Berkeley Geochronology Center Special Publication 5, $110 \mathrm{p}$.

Ludwig K. 2009b. User's manual for Isoplot 3.70. Berkeley, Berkeley Geochronology Center Special Publication 4, $76 \mathrm{p}$.

Mariano G., Neves S.P., Siva Filho A.F., Guimarães I.P. 2001. Diorites of the high-K calc-alkalic association: geochemistry and $\mathrm{Sm}-\mathrm{Nd}$ data and implications for the evolution of the Borborema Province, Northeast Brazil. International Geology Review, 43(10):921-929. https://doi. org/10.1080/00206810109465056

Menezes Filho N.R., Santos R.A., Souza J.D. 1988. Programa de Levantamentos Geológicos Básicos do Brasil: carta geológica, carta metalogenética/previsional - Escala 1:100.000 (Folha SC24-Z-A-II Jeremoabo) Estado da Bahia. Brasília, DNPM/CPRM, 114 p.

Morrison G.W. 1980. Characteristics and tectonic setting of the shoshonite rock association. Lithos, 13(1):97-108. https://doi. org/10.1016/0024-4937(80)90067-5

Müller D., Rock N.M.S., Groves D.I. 1992. Geochemical discrimination between shoshonitic and potassic volcanic rocks in different tectonic settings: a pilot study. Mineralogy and Petrology, 46(4):259-289. https:// doi.org/10.1007/BF01173568

Nakamura N. 1974. Determination of REE, Ba, Fe, Mg, $\mathrm{Na}$ and $\mathrm{K}$ in carbonaceous and ordinary chondrites. Geochimica et Cosmochimica Acta, 38(5):757-775. https://doi.org/10.1016/0016-7037(74)90149-5

Narduzzi F., Farina F., Stevens G., Lana C., Nalini Jr. H.A. 2017. Magmatic garnet in the Cordilleran-type Galiléia granitoids of the Araçuaí belt (Brazil): evidence for crystallization in the lower crust. Lithos, 282-283:8297. https://doi.org/10.1016/J.LITHOS.2017.02.017

Nesbitt H.W., Young G.M. 1982. Early Proterozoic climates and plate motions inferred from major element chemistry of lutites. Nature, 299(5885):715-717. https://doi.org/10.1038/299715a0

Neves S.P., Mariano G. 1997. High-K calc-alkalic plutons in Northeast Brazil: origin of the biotite diorite/quartz monzonite to granite association and implications for the evolution of the Borborema Province. International Geology Review, 39(7):621-638. https://doi. org/10.1080/00206819709465292

Neves S.P., Rangel da Silva J.M., Bruguier O. 2016. The transition zone between the Pernambuco-Alagoas Domain and the Sergipano Belt (Borborema Province, NE Brazil): geochronological constraints on the ages of deposition, tectonic setting and metamorphism of metasedimentary rocks. Journal of South American Earth Sciences, 72:266-278. https://doi. org/10.1016/J.JSAMES.2016.09.010

Oliveira A.C.S. 2014. Petrogênese do stock granítico Monte Alegre, Noroeste do Domínio Macururé, Faixa Sergipana. MS Dissertation, Universidade Federal de Sergipe, São Cristóvão, 130 p.

Oliveira E.P., Bueno J.F., McNaughton N.J., Silva Filho A.F., Nascimento R.S., Donatti-Filho J.P. 2015a. Age, composition, and source of continental arc- and syn-collision granites of the Neoproterozoic Sergipano Belt, Southern Borborema Province, Brazil. Journal of South American Earth Sciences, 58:257-280. https://doi.org/10.1016/J.JSAMES.2014.08.003

Oliveira E.P., McNaughton N.J., Windley B.F., Carvalho M.J., Nascimento R.S. 2015b. Detrital zircon U-Pb geochronology and whole-rock Ndisotope constraints on sediment provenance in the Neoproterozoic Sergipano Orogen, Brazil: from early passive margins to late foreland basins. Tectonophysics, 662:183-194. https://doi.org/10.1016/J. TECTO.2015.02.017

Oliveira E.P., Toteu S.F., Araújo M.N.C., Carvalho M.J., Nascimento R.S., Bueno J.F., McNaughton N., Basilici G. 2006. Geologic correlation between the Neoproterozoic Sergipano belt (NE Brazil) and the Yaoundé belt (Cameroon, Africa). Journal of African Earth Sciences, 44(4-5):470-478. https://doi.org/10.1016/J.JAFREARSCI.2005.11.014

Oliveira E.P., Windley B.F., Araújo M.N.C. 2010. The Neoproterozoic Sergipano Orogenic Belt, NE Brazil: a complete plate tectonic cycle in Western Gondwana. Precambrian Research, 181(1-4):64-84. https://doi. org/10.1016/J.PRECAMRES.2010.05.014

Oliveira E.P., Windley B.F., McNaughton N.J., Bueno J.F., Nascimento R.S., Carvalho M.J., Araújo M.N.C. 2017. The Sergipano Belt. In: Heilbron M., Cordani U.G., Alkmim F.F. (eds.). São Francisco Craton, Eastern Brazil: Tectonic Genealogy of a Miniature Continent. Cham, Springer International Publishing, p. 241-254. https://doi. org/10.1007/978-3-319-01715-0_13

Passchier C.W., Trouw R.A.J. 2005. Microtectonics. $2^{\text {nd }}$ ed. Berlin, SpringerVerlag, 366 p. https://doi.org/10.1007/3-540-29359-0

Paterson S.R., Vernon R.H., Tobisch O.T. 1989. A review of criteria for the identification of magmatic and tectonic foliations in granitoids. Journal of Structural Geology, 11(3):349-363. https://doi. org/10.1016/0191-8141(89)90074-6

Patiño Douce A.E., Beard J.S. 1995. Dehydration-melting of biotite gneiss and quartz amphibolite from 3 to 15 kbar. Journal of Petrology, 36(3):707738. https://doi.org/10.1093/petrology/36.3.707 
Patiño Douce A.E., Harris N. 1998. Experimental constraints on himalayan anatexis. Journal of Petrology, 39(4):689-710. https://doi.org/10.1093/ petroj/39.4.689

Pe-Piper G., Piper D.J.W., Koukouvelas I., Dolansky L.M., Kokkalas S. 2009. Postorogenic shoshonitic rocks and their origin by melting underplated basalts: The Miocene of Limnos, Greece. Geological Society of America Bulletin, 121(1-2):39-54. https://doi.org/10.1130/B26317.1

Pearce J.A. 1982. Trace element characteristics of lavas from destructive plate boundaries. In: Thorpe R.S. (ed.). Orogenic Andesites and Related Rocks. Chichester, John Wiley and Sons, p. 528-548.

Pearce J.A. 1983. Role of the sub-continental lithosphere in magma genesis at active continental margins. In: Hawkesworth C.J., Norry M.J. (eds.), Continental Basalts and Mantle Xenoliths. Cheshire, Shiva Publications, p. 230-249.

Pearce J.A. 2008. Geochemical fingerprinting of oceanic basalts with applications to ophiolite classification and the search for Archean oceanic crust. Lithos, 100(1-4):14-48. https://doi.org/10.1016/J. LITHOS.2007.06.016

Pearce J.A. 2014. Immobile Element Fingerprinting of Ophiolites. Elements, 10(2):101-108. https://doi.org/10.2113/gselements.10.2.101

Pearce J.A., Harris N.B.W., Tindle A.G. 1984. Trace element discrimination diagrams for the tectonic interpretation of granitic rocks. Journal of Petrology, 25(4):956-983. https://doi.org/10.1093/petrology/25.4.956

Peccerillo A., Taylor S.R. 1976. Geochemistry of Eocene calc-alkaline volcanic rocks from the Kastamonu area, Northern Turkey. Contributions to Mineralogy and Petrology, 58(1):63-81. https://doi.org/10.1007/ BF00384745

Pereira F.S., Conceição J.A., Rosa M.L.S., Conceição H. 2017a. Stock Lagoa de Dentro, Domínio Macururé, Sistema Orogênico Sergipano: geologia, petrografia e geoquímica. Scientia Plena, 13(7). https://doi.org/10.14808/ sci.plena.2017.025302

Pereira F.S., Rosa M.L.S., Conceição H. 2019. Condições de colocação do magmatismo máfico do Domínio Macururé, Sistema Orogênico Sergipano: Maciço Capela. Geologia USP. Série Cientifica, 19(3):3-29. https://doi. org/10.11606/issn.2316-9095.v19-151464

Pereira F.S., Rosa M.L.S., Conceição J.A., Bertotti A.L., Conceição H. 2017b. Evidence for pre-collisional (acid)-basic-ultrabasic magmatism in the Sergipano Orogenic System, Northeast Brazil. In: The $27^{\text {th }}$ Goldschmidt Conference. Paris, Abstracts..., p. 3113.

Plank T. 2014. The chemical composition of subducting sediments. Treatise on Geochemistry, 4:607-629. https://doi.org/10.1016/ B978-0-08-095975-7.00319-3

Roberts M.P., Clemens J.D. 1993. Origin of high-potassium, calcalkaline, I-type granitoids. Geology, 21(9):825-828. https://doi. org/10.1130/0091-7613(1993)021<0825:oohpta $>2.3 . c 0 ; 2$

Rollinson H. 1993. Using geochemical data: evaluation, presentation, interpretation. London, Routledge, $384 \mathrm{p}$.

Rudnick R.L., Gao S. 2003. Composition of the continental crust. Treatise on Geochemistry, 3:1-64. https://doi.org/10.1016/B0-08-043751-6/03016-4

Santos I.S., Conceição H., Rosa M.L.S., Marinho M.M. 2019. Magmatismos shoshonítico e cálcio-alcalino de alto potássio pós-orogênico $(615 \mathrm{Ma})$ na porção leste do Domínio Macururé, Sistema Orogênico Sergipano: Stocks Propriá, Amparo do São Francisco e Fazenda Alvorada. Geologia USP. Série Científica, 19(1):9-116.https://doi.org/10.11606/issn.2316-9095.v19-141362

Santos L.O. 2014. Estudo petrográfico e geoquímico dos corpos gabróicograníticos de Capela e Dores, Domínio Macururé, Cinturão Sergipano. Universidade Federal de Sergipe, São Cristóvão, 85 p.

Santos R.A., Martins A.A.M., Neves J.P., Leal R.A. 1998. Programa de Levantamentos Geológicos Básicos do Brasil: Geologia e recursos minerais do Estado de Sergipe. Escala 1:250.000. Texto explicativo do mapa geológico do Estado de Sergipe. Salvador, CPRM/DIEDIG/DEPAT; CODISE, $156 \mathrm{p}$

Sato K., Tassinari C., Basei M.A.S., Siga Júnior O., Onoe A., Souza M. 2014 Microssonda Iônica de Alta Resolução e de Alta Sensibilidade (SHRIMP IIe/MC) do Instituto de Geociências da Universidade de São Paulo, Brasil: método analítico e primeiros resultados. Geologia USP. Série Científica, 14(3):3-18. https://doi.org/10.5327/Z1519-874X201400030001

Shand S.J. 1943. The Eruptive Rocks. $2^{\text {nd }}$ Ed. New York, John Wiley, 444 p.
Sial A.N., Toselli A.J., Saavedra J., Parada M.A., Ferreira V.P. 1999. Emplacement, petrological and magnetic susceptibility characteristics of diverse magmatic epidote-bearing granitoid rocks in Brazil, Argentina and Chile. Lithos, 46(3):367-392. https://doi.org/10.1016/ S0024-4937(98)00074-7

Silva Filho A.F., Guimarães I.P., Dantas E., Cocentino L.M., Lima D.R., Rufino E. 2014. Geochemistry and gechronology of syn-collision to syn- transcurrence Ediacaran transalkaline granites from the PEAL domain, Borborema Province, NE Brazil. Comunicações Geológicas, 101(1):325-329.

Silva C.C. 2014. Petrologia e geocronologia do stock granodiorítico Lagoa do Roçado, Domínio Macururé, Faixa Sergipana-SE. MS Dissertation, Universidade Federal de Sergipe, São Cristóvão, 92 p.

Silva J.M.R., Campos Neto M.C., Brito Neves B.B. 1995. Deformação e metamorfismo principais de uma parte da Faixa Sul-Alagoana (Complexo Macururé), Sistema de Dobramentos Sergipano, Nordeste do Brasil. Revista Brasileira de Geociências, 25(4):343-350.

Silva T.R., Ferreira V.P., Lima M.M.C., Sial A.N. 2016. Two stage mantlederived granitic rocks and the onset of the Brasiliano orogeny: Evidence from Sr, Nd, and O isotopes. Lithos, 264:189-200. https://doi.org/10.1016/J. LITHOS.2016.08.030

Silva Filho A.F., Guimarães I.P., Brito M.E.L., Pimentel M.M. 1997. Geochemical signatures of main neoproterozoic late-tectonic granitoids from the proterozoic Sergipano Fold Belt, Brazil: significance for the Brasiliano Orogeny. International Geology Review, 39(7):639-659. https:// doi.org/10.1080/00206819709465293

Silva Filho A.F., Guimarães I.P., Santos L., Armstrong R., Van Schmus W.R. 2016. Geochemistry, U-Pb geochronology, Sm-Nd and O isotopes of ca. $50 \mathrm{Ma}$ long ediacaran high-K syn-collisional magmatism in the Pernambuco Alagoas Domain, Borborema Province, NE Brazil. Journal of South American Earth Sciences, 68:134-154. https://doi.org/10.1016/J. JSAMES.2015.12.013

Silva Filho M.A., Bomfim L.F.C., Santos R.A., Leal R.A., Santana A.C. Filho P.A.B. 1979. Geologia da Geossinclinal Sergipana e do seu embasamento - Alagoas, Sergipe e Bahia: Projeto Baixo São Francisco/Vaza-Barris. Brasília: DNPM/CPRM.

Smith E.I., Sánchez A., Walker J.D., Wang K. 1999. Geochemistry of mafic magmas in the Hurricane Volcanic Field, Utah: implications for small- and large-scale chemical variability of the lithospheric mantle. The Journal of Geology, 107(4):433-448. https://doi.org/10.1086/314355

Soares H.S., Sousa C.S., Rosa M.L.S., Conceição H. 2019. Petrologia dos Stocks Santa Maria, Monte Pedral, Bom Jardim, Boa Esperança e Niterói, Suíte Intrusiva Serra do Catu, Estado de Sergipe, NE Brasil. Geologia USP. Série Científica, 19(4):63-84.https://doi.org/10.11606/issn.2316-9095.v19-156598

Sousa C.S., Soares H.S., Rosa M.L.S., Conceição H. 2019. Petrologia e geocronologia do Batólito Rio Jacaré, Domínio Poço Redondo, Sistema Orogênico Sergipano, NE do Brasil. Geologia USP. Série Científica, 19(2):171-194. https://doi.org/10.11606/issn.2316-9095.v19-152494

Spalletta B.M., Oliveira E.P. 2017. Idades LA-SF-ICPMS em zircão dos quartzitos da Formação Santa Cruz, Orógeno Sergipano, Alagoas. In: Simpósio de Geologia do Nordeste, 27., João Pessoa. Anais..

Stacey J.S., Kramers J.D. 1975. Approximation of terrestrial lead isotope evolution byatwo-stagemodel.EarthandPlanetary ScienceLetters, 26(2):207221. https://doi.org/https://doi.org/10.1016/0012-821X(75)90088-6

Sun S.-S., McDonough W.F. 1989. Chemical and isotopic systematics of oceanic basalts: implications for mantle composition and processes. In Saunders A.D., Norry M.J. (eds.), Magmatism in the Ocean Basins. London, Geological Society of London, Special Publications, 42, p. 313-345. https:// doi.org/10.1144/GSL.SP.1989.042.01.19

Thompson R.N. 1982. Magmatism of the British Tertiary Volcanic Province Scottish Journal of Geology, 18(1):50-107. https://doi.org/10.1144/sgg18010049

Toteu S.F., Penaye J., Djomani Y.P. 2004. Geodynamic evolution of the PanAfrican belt in central Africa with special reference to Cameroon. Canadian Journal of Earth Sciences, 41 (1):73-85. https://doi.org/10.1139/e03-079

Toteu S.F., Van Schmus W.R., Penaye J., Michard A. 2001. New U-Pb and $\mathrm{Sm}-\mathrm{Nd}$ data from north-central Cameroon and its bearing on the pre-Pan African history of central Africa. Precambrian Research, 108(1-2):45-73. https://doi.org/10.1016/S0301-9268(00)00149-2 
Trompette R. 1997. Neoproterozoic ( $600 \mathrm{Ma}$ ) aggregation of Western Gondwana: a tentative scenario. Precambrian Research, 82(1-2):101-112. https://doi.org/10.1016/S0301-9268(96)00045-9

Turner S., Arnaud N., Liu J., Rogers N., Hawkesworth C., Harris N., Kelley S., Van Calsteren P., Deng W. 1996. Post-collision, shoshonitic volcanism on the Tibetan plateau: implications for convective thinning of the lithosphere and the source of ocean island basalts. Journal of Petrology, 37(1):45-71. https://doi.org/10.1093/petrology/37.1.45

Van Schmus W.R., Oliveira E.P., Silva Filho A.F., Toteu S.F., Penaye J., Guimarães I.P. 2008. Proterozoic links between the Borborema Province, NE Brazil, and the Central African Fold Belt. Geological Society, London, Special Publications, 294(1):69-99. https://doi.org/10.1144/SP294.5

Watson E.B. 1982. Basalt contamination by continental crust: some experiments and models. Contributions to Mineralogy and Petrology, 80(1):73-87. https://doi.org/10.1007/BF00376736

Williams I.S. 1997. U-Th-Pb geochronology by ion microprobe. In: McKibben M.A., Shanks W.C., Ridley W.I. (eds.), Applications of Microanalytical Techniques to Understanding Mineralizing Processes. Reviews in Economic Geology, 7, Society of Economic Geologists, p. 1-36.
Williams I.S., Claesson S. 1987. Isotopic evidence for the Precambrian provenance and Caledonian metamorphism of high grade paragneisses from the Seve Nappes, Scandinavian Caledonides. Contributions to Mineralogy and Petrology, 97(2):205-217. https://doi.org/10.1007/ BF00371240

Wilson M. 1989. Igneous Petrogenesis: a Global Tectonic Approach. Dordrecht, Springer Netherlands, 466 p. https: //doi.org/10.1007/978-1-4020-6788-4

Wood D.A. 1980. The application of a Th-Hf-Ta diagram to problems of tectonomagmatic classification and to establishing the nature of crustal contamination of basaltic lavas of the British Tertiary Volcanic Province. Earth and Planetary Science Letters, 50(1):11-30. https://doi. org/10.1016/0012-821X(80)90116-8

Woodhead J.D., Eggins S.M., Johnson R.W. 1998. Magma genesis in the New Britain Island Arc: further insights into melting and mass transfer processes. Journal of Petrology, 39(9):1641-1668. https://doi.org/10.1093/ petroj/39.9.1641

Zen E., Hammarstrom J.M. 1984. Magmatic epidote and its petrologic significance. Geology, 12(9):515-518. https://doi. org/10.1130/0091-7613(1984)12<515:MEAIPS>2.0.CO;2 